\title{
Poliittinen osallistuminen osana kotoutumista
} Maahan muuttaneiden äänestysaktiivisuus vuoden 2017 kuntavaaleissa

TIIVISTELMÄ Artikkelissa tarkastellaan rekisteriaineiston valossa Suomeen muuttaneiden venäläis-, virolais-, somalialais- ja ruotsalaistaustaisten äänestämistä vuoden 2017 kuntavaaleissa. Tutkimuksessa keskitytään siihen, miten sosiaalisen taustan eri tekijät, kuten sukupuoli, ikä, ammattiasema, henkilökohtaiset tulot, siviilisääty ja kansalaisuus, vaikuttivat äänestysaktiivisuuteen eri ryhmissä. Tutkimuksen keskeisin havainto on, että turvatumpi sosiaalinen asema nosti äänestystodennäköisyyttä kaikissa muissa ryhmissä paitsi somalialaistaustaisten osalta. Sen sijaan somalit äänestivät aktiivisesti muita heikommasta sosioekonomisesta asemastaan huolimatta. Artikkeli tuo uutta tietoa ulkomaalaistaustaisten ryhmien äänestyskäyttäytymisestä ja luo siten pohjaa ulkomaalaistaustaisten poliittisen osallisuuden tutkimukselle Suomessa. 


\section{JOHDANTO}

Keskustelussa Suomeen muuttaneiden kotoutumisesta ja kotouttamisesta keskitytään usein ensisijaisesti siihen, kuinka maahan muuttaneet löytävät työpaikan tai sopeutuvat suomalaiseen kulttuuriin ja yhteiskuntaan. Kuitenkin myös politiikkaan kiinnittyminen on keskeinen osa maahanmuuttotaustaisen väestön kokonaisvaltaista kotoutumista (esim. Saukkonen 2020, 19). Yksilön kokemuksilla kyvyistään vaikuttaa omiin tai oman ryhmänsä intresseihin on merkittävä vaikutus siihen, missä määrin hän kokee olevansa osa ympäröivää yhteiskuntaa (esim. Bird ym. 2011; Morales ja Giugni 2011). Vastaavasti tunne ja kokemukset, joiden mukaan poliittinen areena ei ole kaikille avoin etnisestä taustasta riippumatta, ovat omiaan aiheuttamaan ulkopuolisuuden tunteita, heikentämään sidettä ympäröivään yhteisöön ja luomaan etniseen taustaan kytkeytyviä yhteiskunnallisia jakolinjoja (Dancygier 2010).

Tässä artikkelissa tarkastellaan äänestysaktiivisuutta Suomen neljässä suurimmassa ulkomaalaistaustaisessa väestöryhmässä (Tilastokeskus 2020a) vuoden 2017 kuntavaaleissa. Tarkastelu kohdistuu venäläis-, virolais-, somalialais- ja ruotsalaistaustaisiin, jotka ovat syntyneet ulkomailla ja muuttaneet itse Suomeen. Artikkelissa tutkitaan rekisteriaineiston valossa, miten sosiaalisen taustan eri tekijät vaikuttivat näiden ryhmien äänestysaktiivisuuteen. Tutkimuskohteen rajaus perustuu väestöryhmien koon ohella myös tutkimusaineiston saatavuuteen, sillä Tilastokeskus luovutti tietosuojasyistä tiedot vain suurimmista ryhmistä.

Tutkimus rajautuu kuntavaaleihin, joissa esteet ulkomaalaistaustaisten osallistumiselle ovat kaikkein matalimmat: toisin kuin eduskunta- ja presidentinvaaleissa, kuntavaaleissa voivat äänestää myös he, joilla ei ole Suomen kansalaisuutta. EU:n ja Pohjoismaiden kansalaisten osalta riittää, että henkilöllä on ollut virallinen kotikunta Suomessa 51 päivää ennen vaalia. Muiden maiden kansalaiset saavat äänestää, mikäli heillä on ollut kotikunta Suomessa kahden vuoden ajan. Kuntavaaleissa etäisyys ehdokkaiden ja äänestäjien välillä on huomattavasti pienempi kuin esimerkiksi eduskuntavaaleissa. Varsin usein moni kuntalainen tuntee oman ehdokkaansa henkilökohtaisesti (Borg 2018, 132).

Suomeen muuttaneiden äänestämiseen tai äänestämättä jättämiseen vaikuttavista tekijöistä tiedetään toistaiseksi melko vähän (ks. kuitenkin Kuusio ym. 2020; Valaste ja Wass 2019; Wass ja Weide 2015; Wass ym. 2015; Weide ja Saukkonen 2013). Yksittäisten maahanmuuttotaustaisten vähemmistöryhmien osalta tietämys on tätäkin niukempaa (ks. kuitenkin somalialaistaustaisten äänestyskäyttäytymisestä Pirkkalainen ym. 2016). Tutkimukset osoittavat, että äänestämättä jättäminen on useimmiten seurausta vaaleja koskevan tiedon puutteesta (Kuusio ym. 2020, 73), mikä oletettavasti on yhteydessä Suomeen muuttaneiden heikompiin mahdollisuuksiin saada tietoa yhteiskunnasta ja politiikasta kielellä, jota he ymmärtävät. Mitä tiiviimmät siteet suomalaiseen yhteiskuntaan maahan muuttaneet solmivat esimerkiksi solmimalla avioliiton Suomen kansalaisen kanssa tai saamalla perheenlisäystä, sitä todennäköisemmin he kuitenkin äänestävät (Valaste ja Wass 2019; Wass ja Weide 2015). Suomeen muuttaneiden puolue- ja ehdokasvalintaan vaikuttavista tekijöistä ei toistaiseksi ole lainkaan tutkimustietoa.

Tutkitun tiedon puute johtuu pitkälti siitä, että ulkomaalaistaustaisen väestön määrä Suomessa on pitkään ollut kansainvälisellä mittapuulla varsin pieni. Vielä 2020-luvulla väestön monimuotoistuminen koskettaa pääosin eteläistä Suomea ja maamme suurimpia kaupunkeja (Saukkonen 2020, 34). On kuitenkin selvää, että sitä mukaa kun ulkomaalaistaustaisen väestön määrä 
kasvaa, uusien etnisten vähemmistöjen poliittisesta aktiivisuudesta ja edustuksesta poliittisissa instituutioissa tulee yhä keskeisempi yhteiskunnallinen kysymys. Asiantuntijat myös korostavat, kuinka ulkomaalaistaustaisten kotoutumisessa ja siten myös politiikkaan kiinnittymisessä on tunnistettava moninaisuus paitsi eri ryhmien välillä myös niiden sisällä (esim. Kaihovaara ym. 2020; Saukkonen 2020).

Artikkelin äänestysaktiivisuuden tarkastelu perustuu Tilastokeskuksen tuottamaan yksilötason rekisteriaineistoon vuoden 2017 kuntavaaleista, joka puolestaan pohjautuu oikeusministeriön ylläpitämään sähköiseen äänioikeusrekisteriin. ${ }^{1}$ Rekisteriaineisto antaa tarkan kuvan äänestysaktiivisuudesta toisin kuin esimerkiksi kyselyaineistot, joihin vastaavat selvästi useammin henkilöt, jotka ovat muutoinkin yhteiskunnallisesti aktiivisia (Karp ja Brockington 2005). Maahanmuuttotaustaisten ja kielivähemmistöön kuuluvien vastaajien tavoittaminen kyselytutkimuksiin on selvästi hankalampaa kuin valtaväestön, minkä vuoksi on todennäköistä, että näihin ryhmiin kuuluvien vastaajien joukossa on vielä korostuneemmin yhteiskunnallisesti aktiivisia henkilöitä. Rekisteripohjaisen tarkastelun etuna on myös se, ettei vastaajien tarve antaa sosiaalisesti hyväksyttäviä vastauksia - eli väittää äänestäneensä vaikkei näin olisi tehnyt - vääristä tutkimustuloksia. Toisaalta rekisteripohjainen tarkastelu ei mahdollista äänestyspäätöksen taustalla olevien arvojen ja asenteiden analysointia, mikä tarkoittaa, että tässä artikkelissa keskitytään sosiaalisen taustan merkitykseen eri ryhmissä2. Kansainvälisesti maahan muuttaneiden äänestyskäyttäytymisen tutkimista on rajoittanut paljon se, että empiiristä aineistoa on saatavilla vain niukasti ja pääsääntöisesti se on nimenomaan kysely- eikä rekisteripohjaista.

Artikkelissa perehdytään ensin aiempiin tutkimustuloksiin maahan muuttaneiden sosiaalisen taustan vaikutuksesta äänestämiseen. Tämän jälkeen esitetään tiivistys siitä, miten poliittinen järjestelmä ja poliittisen osallistumisen kulttuuri eroavat Venäjällä, Virossa, Somaliassa ja Ruotsissa ja pohditaan, mikä vaikutus taustamaan järjestelmätason tekijöillä on äänestysaktiivisuudelle Suomessa. Vastaavasti keskustellaan myös siitä, miten esimerkiksi yhdistystoimintaan osallistuminen, pääsy työmarkkinoille sekä kokemukset syrjinnästä Suomessa voivat vaikuttaa ryhmien poliittiseen osallisuuteen. Tutkimuksen empiirisessä osiossa tarkastellaan aluksi eri ryhmien äänestysaktiivisuutta vuoden 2017 kuntavaaleissa, minkä jälkeen äänestysaktiivisuutta mallinnetaan tilanteessa, jossa sosiaaliseen taustaan liittyvät muuttujat on vakioitu. Artikkeli tuo uutta tietoa maamme suurimpien ulkomaalaistaustaisten ryhmien äänestyskäyttäytymisestä ja luo siten pohjaa ulkomaalaistaustaisten poliittisen osallisuuden ja osallistumisen tutkimukselle Suomessa.

\section{SUOMEEN MUUTTANEIDEN ÄÄNESTYSAKTIIVISUUTEEN VAIKUTTAVIA TEKIJÖITÄ}

Äänestämistä pidetään yhtenä keskeisimmistä poliittisen osallistumisen muodoista, sillä vaaleilla valittavilla instituutioilla on merkittävä rooli demokraattisissa poliittisissa järjestelmissä (esim. Wass ja Borg 2016). Äänestämistä pidetään myös yhtenä keskeisenä ulkomaalaistaustaisen väestön kotoutumisen indikaattorina (Työ- ja elinkeinoministeriö 2020). Demokratian toimivuutta voidaankin arvioida sen kyvyllä luoda osallistumisen edellytykset eri väestöryhmille kuten muualta lähtöisin oleville äänestäjille. Äänestäminen on tärkeää, sillä poliittisessa päätöksenteossa 
edistetään ensisijaisesti äänioikeuttaan käyttävien ryhmien intressejä. Puolueet myös rekrytoivat ehdokkaita ensisijaisesti niistä ryhmistä, joilta ne uskovat saavansa mahdollisimman paljon kannatusta ja joiden ne uskovat suhtautuvan myönteisesti aktivointipyrkimyksiin. (Brady ym. 1999; Sipinen ja Koskimaa 2020.) Nimenomaan äänestämisen katsotaan ilmentävän kiinnostusta ja kiinnittymistä poliittiseen yhteisöön (Winkler 1993), joskin poliittinen osallistuminen kattaa lukuisia muitakin osallistumismuotoja. Muiden osallistumismuotojen on kuitenkin nähty pikemminkin täydentävän vaaliosallistumista, sillä ne, jotka äänestävät, osallistuvat myös muilla keinoin todennäköisemmin kuin ne jotka eivät äänestä (Myllyniemi 2014, 28-29).

Jo varhaisimmista äänestyskäyttäytymistä tarkastelevista tutkimuksista asti on ollut selvää, että äänestäminen on sitä todennäköisempää, mitä turvatummassa yhteiskunnallisessa asemassa yksilö on eli mitä korkeampi on hänen sosioekonominen asemansa (Campbell ym. 1960; Verba ja Nie 1972). Mitä matalammaksi vaalien äänestysaktiivisuus kokonaisuudessaan jää, sitä jyrkempiä sosioekonomiseen taustaan kytkeytyvät vinoumat eri ryhmien välillä ovat (Persson ym. 2013). Yksilötasolla päätös käydä äänestämässä riippuu erilaisista osallistumista tukevista taidoista, jotka ovat vahvassa yhteydessä yksilön sosioekonomiseen asemaan kuten koulutukseen (Brady ym. 1995; Wass ja Borg 2016). Myös poliittisella sosialisaatiolla on keskeinen merkitys; mitä myönteisemmin oma perhe, ystävät ja muu lähipiiri suhtautuvat äänestämiseen ja kannustavat poliittiseen aktiivisuuteen, sitä todennäköisemmin yksilökin äänestää (esim. Verba ym. 2005). Äänestyspäätökseen vaikuttaa lisäksi yksilöä ympäröivä konteksti eli niin kutsuttu poliittinen mahdollisuusrakenne, joka tarkoittaa, että poliittisen järjestelmän ja vaalikontekstin ominaispiirteet joko kasvattavat tai heikentävät yksilöiden ja ryhmien halukkuutta ja mahdollisuuksia äänestää (Bird ym. 2011; Morales ja Giugni 2011; Wass ja Borg 2016).

Suomeen muuttaneiden matala äänestysaktiivisuus kuntavaaleissa on aiemmissa tutkimuksissa yhdistetty heidän muuta väestöä keskimääräistä heikompaan sosioekonomiseen asemaansa (Pirkkalainen ym. 2016; Wass ja Weide 2015; Wass ym. 2015). Samalla niin kotimaisissa kuin kansainvälisissä tutkimuksissa on kuitenkin havaittu, ettei sosioekonomisen taustan vaikutus maahanmuuttotaustaisten äänestäjien äänestyskäyttäytymiseen ole yhtä suoraviivainen kuin valtaväestön keskuudessa. Esimerkiksi Hanna Wass ja Marjukka Weide $(2015,29)$ puhuvat "erilaisen vasteen mallista" havaitessaan, kuinka iällä ja koulutuksella on lievempi yhteys äänestämiseen maahanmuuttotaustaisten kuin syntyperäisten äänioikeutettujen keskuudessa. Iän vähäisempää vaikutusta on selitetty sillä, että toisessa poliittisessa kontekstissa varttuneilla äänestäjillä vaalitilanne on uusi iästä riippumatta ja siten äänestämiseen liittyvät "käynnistämiskustannukset" ovat vanhempina maahan muuttaneilla yhtä suuria kuin nuorempana muuttaneilla (ks. myös Black ym. 1987). Korkea koulutus ja sen myötä saavutettu vakaa asema työmarkkinoilla ovat usein myös yhteydessä keskeiseen asemaan sellaisissa sosiaalisissa verkostoissa, joissa poliittinen rekrytoituminen ja aktivointipyrkimykset ovat yleisempiä (Persson 2015). Suomeen muuttaneiden tapauksessa lähtömaassa hankittu korkeakoulututkinto ei kuitenkaan aina takaa korkeaa asemaa uuden asuinmaan työmarkkinoilla (Larja 2019), eikä turvattu työmarkkina-asema puolestaan samalla tavoin takaa maahan muuttaneille yhtä monipuolisia sosiaalisia verkostoja kuin valtaväestölle. Kaikkialla koulutus ei myöskään tähtää niin sanotun kunnon kansalaisen ihanteeseen ja siihen liittyvään äänestysvelvollisuuden edistämiseen (Wolfinger ja Rosenstone 1980, 8). Tästä huolimatta voidaan yhä olettaa, että turvattu sosiaalinen asema tukee poliittista osallisuutta. 
Maahanmuuttotaustalla on usein yhteys yksilöiden ja ryhmien yhteiskunnalliseen asemaan ja henkilökohtaisiin osallistumista tukeviin voimavaroihin. Esimerkiksi sopivan puolueen ja ehdokkaan etsiminen on todennäköisesti huomattavasti työläämpää henkilölle, jolle uuden asuinmaan poliittinen järjestelmä ja sen toimijat eivät ole entuudestaan tuttuja. Suomalainen vaalijärjestelmä, jossa äänestäjän on puolueen lisäksi äänestettävä aina myös ehdokasta, vaatiikin äänestäjältä enemmän kognitiivista työtä verrattuna järjestelmään, jossa äänensä voi halutessaan osoittaa koko puolueen ehdokaslistalle (von Schoultz 2018). Myös sillä, missä määrin vaaleja koskevaa tietoa on tarjolla omalla äidinkielellä tai kielellä, jota yksilö sujuvasti ymmärtää, on oletettavasti keskeinen merkitys äänestämiselle. Tuoreen FinMonik-tutkimuksen mukaan tiedon puute on keskeisin äänestämättä jättämisen syy eri ulkomaalaistaustaisten ryhmien keskuudessa. Sen mainitsi peräti kolmannes kaikista vastaajista. Selvästi pienempi osa (15-18\%) mainitsi äänestämättä jättämisen olevan yhteydessä poliittisen kiinnostuksen, poliittisen luottamuksen, sopivan ehdokkaan tai vaikutusmahdollisuuksien puutteeseen. (Kuusio ym. 2020.)

Myös perheellä on suora yhteys yksilön käytössä oleviin resursseihin, ja aiemmissa tutkimuksissa onkin havaittu positiivinen yhteys avioliiton ja äänestämisen välillä. Tämä liittyy ennen kaikkea siihen, että äänestäminen on sosiaalinen teko. Puolison kanssa voi paitsi keskustella vaaleista myös käydä yhdessä äänestämässä (Wolfinger ja Wolfinger 2008). Lisäksi tiedetään, että kahden aikuisen muodostaman kotitalouden toimeentulo on keskimäärin yhden aikuisen talouksia turvatumpi (Tilastokeskus 2018). Naimisissa olevat ovat arvoiltaan myös keskimääräistä konservatiivisempia, mikä on yhteydessä siihen, että äänestäminen nähdään kansalaisvelvollisuutena (Denver 2008). Aiemmissa tutkimuksissa on lisäksi osoitettu, että avioliitto syntyperäisen kansalaisen kanssa on erityisen merkityksellistä ulkomaalaistaustaisten äänestämistodennäköisyydelle (Valaste ja Wass 2019; Wass ym. 2015). Suomalaistaustainen puoliso on merkki tiiviimmistä vuorovaikutuksellisista suhteista valtaväestöön. Tämän lisäksi voidaan olettaa, että suomalainen puoliso kykenee välittämään paremmin tietoa suomalaisesta poliittisesta järjestelmästä ja sen toimijoista ulkomaalaistaustaiseen puolisoon verrattuna.

Aiemmat tutkimukset osoittavat myös kiistatta kansalaisuuden hakemisen ja saamisen voimakkaan positiivisen yhteyden äänestystodennäköisyyteen (Hainmueller ym. 2015; Wass ym. 2015). Tämä sinänsä ei ole yllättävää, onhan kansalaistamisprosessin läpikäyminen selvä indikaattori jonkinasteisesta yhteenkuuluvuuden tunteesta ja pitkäjänteisestä asettumisesta uuteen kotimaahan. Lisäksi Suomen kansalaisuuden saamisen edellytyksenä on osoitus vähintään tyydyttävästä suomen tai ruotsin kielen osaamisesta (Maahanmuuttovirasto 2020), mikä jo itsessään kertoo, että yksilöllä on paremmat mahdollisuudet seurata esimerkiksi vaaliviestintää valtakielisistä medioista.

Naiset äänestävät Suomessa miehiä aktiivisemmin, joskin sukupuolten väliset erot äänestysaktiivisuudessa ovat pieniä (Pikkala ym. 2013). Vaikka Suomi tarjoaa suotuisan ympäristön naisten vaaliosallistumiselle, suuressa osassa muita maailman maita naisten äänestysaktiivisuus on merkittävästi miehiä matalampaa, joskin syyt ilmiön taustalla johtuvat lukuisista eri aikaan ja paikkaan liittyvistä tekijöistä, kuten sukupuolten välisestä työnjaosta perheessä, naisten osallistumisesta työmarkkinoille sekä sitä tukevista perhepoliittisista ratkaisuista (Iverson ja Rosenbluth 2006; Paxton ym. 2007). Tarkastelun kohteena olevien maahan muuttaneiden lähtömaista Venäjällä, Virossa ja Ruotsissa naisten äänestysprosentti on kyselytutkimuksen valossa miehiä 
korkeampi (European Social Survey 2016). Somalian osalta tietoja sukupuolten äänestysaktiivisuudesta on vaikea löytää, mutta ainakin mediassa naisten kerrottiin rekisteröityneen miehiä ahkerammin äänestäjiksi vuoden 2016 parlamenttivaaleissa (esim. Deutsche Welle 2016). On mahdollista, että kyseisistä maista tulleiden keskuudessa vastaava ero voi säilyä myös Suomessa huolimatta siitä, että moni Suomeen muuttaneista naisista kiinnittyy miehiä heikommin työmarkkinoille ja saa sen vuoksi vähemmän mahdollisuuksia vuorovaikutukseen valtaväestön kanssa (Forsander 2007; Larja 2019; Joronen 2007).

Suomeen muuttaneiden osallistumisen ja osallistumattomuuden syyt riippuvat edellä kuvattujen yksilötason tekijöiden lisäksi myös taustamaan poliittisesta järjestelmästä ja poliittisen osallistumisen kulttuurista. Lisäksi merkitystä on sillä, miten suomalainen yhteiskunta eri ulkomaalaistaustaisiin ryhmiin suhtautuu, ja millaiset edellytykset poliittiselle osallisuudelle se tarjoaa.

\section{VENÄLÄISET, VIROLAISET, SOMALIALAISET JA RUOTSALAISET SUOMESSA}

Seuraavaksi tarkastellaan Suomeen Venäjältä, Virosta, Somaliasta ja Ruotsista muuttaneiden välisiä eroja maahanmuuton syihin sekä lähtömaan poliittisiin oikeuksiin ja poliittiseen järjestelmään liittyen. Lisäksi tarkastellaan ryhmien osallistumista yhdistystoimintaan Suomessa samoin kuin syrjintäkokemuksia ja ryhmäidentiteettiä. Tämän osion tavoitteena on esittää taustaoletuksia sille, miten poliittiseen sosialisaatioon lähtömaassa nivoutuvat tekijät samoin kuin suomalaiseen yhteiskuntaan kotoutuminen selittävät äänestämiseen tarvittavien resurssien ja äänestysmotivaation vaihtelua eri ryhmien välillä.

Vuoden 2019 lopussa Suomessa asui hieman alle 75000 ulkomaalaissyntyistä henkilöä, joiden taustamaa (eli pääsääntöisesti äidin syntymämaa) oli Venäjä tai entinen Neuvostoliitto (Tilastokeskus 2020a). Heistä puhutaan jatkossa venäläistaustaisina. Virolaistaustaisia ulkomailla syntyneitä oli noin 43 500, somalialaistaustaisia noin 13000 ja ruotsalaistaustaisia 5000 . Siinä missä somalialaisista lähes kaikki ovat tulleet Suomeen joko turvapaikanhakijoina, pakolaisina tai näiden perheenjäseninä (Tiilikainen 2014, 25-26), muissa ryhmissä syyt Suomeen muuttoon ovat moninaisemmat. Kuitenkin myös muiden ryhmien välillä on havaittavissa selkeitä eroja: siinä missä moni virolainen on muuttanut Suomeen ennen kaikkea työn perässä, venäläisistä ja ruotsalaisista suurin osa on tullut perhesyistä (Pitkänen ym. 2019a; 2019b; Sutela ja Larja 2015; Wahlbeck 2015, 53-63). Lähempi tarkastelu kuitenkin osoittaa, että erityisesti venäläistaustaiset ovat kaikkea muuta kuin yhtenäinen ryhmä (Tanner ja Söderling 2016; Varjonen ym. 2017). Heihin kuuluu perheen, työn ja opiskelun vuoksi muuttaneiden lisäksi myös suuri joukko inkerinsuomalaisia paluumuuttajia, ja he edustavat useita eri kansalaisuuksia ja etnisiä ryhmiä.

Ryhmät eroavat myös sukupuoli- ja ikärakenteiltaan. Tilastokeskuksen (2020a) mukaan 60 prosenttia venäläistaustaisista on naisia. Virolais- ja somalialaistaustaisten osalta sukupuolijakauma on lähellä 50-50 suhdetta siinä missä ruotsalaistaustaisissa naisten osuus jää 43 prosenttiin. Ikäjakaumaltaan selvästi nuorimpia ovat somalialaistaustaiset. Vuoden 2019 lopulla puolet heistä oli alle 30-vuotiaita. Pakolaistaustan ja perheenyhdistämisten vuoksi somalialaistaustaisissa on myös verrattain paljon jo lapsena Suomeen muuttaneita toisin kuin muissa ryhmissä. 
Keski-iältään vanhimpia ovat ruotsalaistaustaiset, joista neljännes oli vähintään 65-vuotiaita. Venäläistaustaisissa vastaava osuus oli reilu kymmenes ja virolais- ja somalialaistaustaisissa vain 3-4 prosenttia. Venäläistaustaisista samoin kuin virolaistaustaisista 59-65 prosenttia oli 30-59-vuotiaita. Ruotsalais- ja somalialaistaustaisista vastaava osuus oli 47.

Ryhmät ovat myös sijoittuneet eri tavoin eri puolille Suomea (Tilastokeskus 2020b). Suomen somalialaistaustaisista neljä viidestä asuu Helsingissä, Espoossa tai Vantaalla. Virolaistaustaisista näissä kaupungeissa asuu noin puolet ja loput pääosin muissa eteläisen Suomen kunnissa. Venäläistaustaisista kaksi viidestä asuu pääkaupunkiseudun suurimmissa kaupungeissa, minkä lisäksi heitä on sijoittunut paljon myös Etelä- ja Itä-Suomen suurimpiin kaupunkeihin. Ruotsalaistaustaisten asutus on muita ryhmiä hajautuneempaa kuitenkin niin, että he ovat sijoittuneet pääasiassa niihin Etelä- ja Länsi-Suomen rannikkokuntiin, jotka ovat joko ruotsinkielisiä tai kaksikielisiä.

Venäjä, Viro ja Ruotsi ovat Suomen naapurimaita, mikä tarkoittaa, että näistä maista tuleville ylirajainen liikkuvuus on eri tavalla mahdollista kuin Afrikan sarvesta Suomeen muuttaneille somalialaisille. Schengen-sopimus takaa virolaisille ja ruotsalaisille oikeuden matkustella maiden välillä täysin vapaasti, mikä mahdollistaa paremmin perhe- ja ystävyyssuhteiden ylläpitämisen kotimaassa. Merkittävä osa eritoten virolaisista elää niin sanotusti toinen jalka Suomessa ja toinen Virossa ilman aikomusta asettua Suomeen pysyvästi (Anniste ja Tammaru 2014; Kährik ja Tammaru 2019; Lagerspetz 2020). Suomessa asumisen pysyvyydellä voidaan olettaa olevan suora yhteys siihen, kuinka tärkeänä yksilö pitää äänestämistä paikallisissa vaaleissa. Niillä, jotka suunnittelevat jäävänsä Suomeen pysyvästi tai ainakin pitkäksi aikaa, on suuremmat intressit vaikuttaa lähiympäristöönsä kuin niillä, jotka ovat maassa vain väliaikaisesti. Pysyvä asuminen on yhteydessä lisääntyneeseen kunnallisten palveluiden käyttöön, mikä potentiaalisesti lisää kiinnostusta siihen, miten ne järjestetään ja siten myös äänestämiseen kuntavaaleissa.

Venäjän, Viron, Somalian ja Ruotsin poliittiset järjestelmät ja kansalaisilleen tarjoamat poliittiset oikeudet eroavat merkittävästi keskenään. Erot näistä maista muuttaneiden poliittisessa sosialisaatiossa ovat siten huomattavia eritoten silloin, kun kyse on aikuisiällä Suomeen muuttaneista. Siinä missä Ruotsin ja Viron demokraattiset poliittiset järjestelmät eivät perusperiaatteiltaan eroa Suomen vastaavasta, Venäjällä ja Somaliassa kansalaisten poliittinen aktiivisuus voi johtaa poliittisen ja etenkin Somaliassa jopa uskonnollisen vainon kohteeksi joutumiseen (Keating ja Waldman 2018; Robinson 2018). Vaikka Viron, Ruotsin ja Suomen väliset erot ovat huomattavasti pienempiä verrattuna epädemokraattisiin Venäjään ja Somaliaan, myös näiden maiden poliittisissa kulttuureissa on eroja, jotka vaikuttavat kansalaisten vaaliosallistumista koskeviin tapoihin ja asenteisiin. Ruotsi on yksi Euroopan vakaimmista ja vanhimmista demokratioista, jossa kansalaisten sananvapaus ja poliittiset oikeudet on turvattu jo sadan vuoden ajan (Sveriges Riksdag 2019). Viro vastaavasti itsenäistyi Neuvostoliitosta vasta 30 vuotta sitten, ja etenkin (uudelleen)itsenäistymisen alkuvaiheessa maan kansalaisyhteiskunta oli heikko ja kansalaisten asenteet poliittisia instituutioita kohtaan kielteisiä (Saarts ja Jakobson 2019; ks. myös Pop-Eleches ja Tucker 2011). Aiemman tutkimuskirjallisuuden valossa voidaan olettaa, että äänestystodennäköisyys on korkeampi demokraattisista maista muuttaneiden keskuudessa kuin epädemokraattisista maista saapuneiden, koska aiemmassa ympäristössä omaksuttu osallistumisnormi on "siirrettävissä" Suomen kontekstiin (Bueker 2005, 105). Toisaalta ei voida sulkea pois mahdollisuutta, että osa epädemokraattisista maista muuttaneista saattaa äänestää 
juuri siitä syystä, että he haluavat käyttää poliittisia oikeuksiaan, joita heillä ei aiemmassa elämässään osana epädemokraattista järjestelmää ollut tarjolla.

Tarkasteltavat ryhmät eroavat toisistaan myös siinä suhteessa, kuinka aktiivisesti he osallistuvat yhdistystoimintaan Suomessa. Siinä missä somaleiden yhdistystoiminta on ollut vilkasta, venäläisten ja virolaisten järjestäytyminen on ollut selvästi vähäisempää (Kuusio ym. 2020, 71). Somalialaiset ovat osallistuneet selvästi muita ulkomaalaistaustaisia ryhmiä useammin etnisiin yhdistyksiin, joissa toimivia yhdistää sama lähtömaa tai etninen tausta (Pirkkalainen 2013; Pyykkönen 2007). Tätä voi selittää merkittäviltä osin se, että niin kutsuttuun "näkyvään vähemmistöön" kuuluminen on vaikeuttanut erityisesti somalialaisten pääsyä osaksi suomalaista yhteiskuntaa (Mubarak ym. 2015; Tiilikainen 2014, 38, 56). Etnisissä järjestöissä toimiminen on kuitenkin tarjonnut somalialaisille keinon muodostaa sosiaalisia verkostoja (Pyykkönen 2007, 72). Vertailluista ryhmistä somalialaiset poikkeavat ihonväriltään valtaväestöstä toisin kuin venäläiset ja virolaiset, jotka erottuvat lähinnä kielen ja nimiensä perusteella. Kaksikielisessä Suomessa ruotsalaiset puolestaan voivat halutessaan sulautua osaksi valtaväestöä. Työn, perhesuhteiden tai opiskelun vuoksi Suomeen muuttaneilla venäläisillä, virolaisilla ja ruotsalaisilla on jo saapuessaan ollut jonkinasteinen kytkös suomalaiseen yhteiskuntaan, eivätkä he ole samalla tavoin tarvinneet etnisiä yhteisöjä ja yhdistyksiä kompensoimaan verkostojen puuttumista (Lagerspetz 2020). Ruotsalaisten etuna on lisäksi mahdollisuus muodostaa tiiviitä suhteita äidinkielenään ruotsia puhuvaan suomalaista syntyperää olevaan väestöön, mikä merkittävällä tavalla edistää ruotsalaisten kotoutumista Suomeen (Wahlbeck 2015). Mikko Lagerspetz $(2020,133)$ tiivistää syitä virolaisten laimeaan järjestäytymisintoon, mikä lienee osin yleistettävissä myös muihin ryhmiin:

Maahanmuuttajat ovat erilaisia ammatiltaan, koulutukseltaan ja elämäntilanteeltaan. Kiinnostuksen kohteet myös muuttuvat Suomessa asutun ajan myötä. Äskettäin Suomeen saapuneille on olennaista vaihtaa kokemuksia toisten Suomessa asuvien virolaisten kanssa, saada tietoa käytännön asioiden järjestämisestä ja myös yksinkertaisesti keskustella äidinkielellään. Kun kielitaito karttuu ja suomalainen yhteiskunta tulee tutummaksi, pelkkä yhdessäolo toisten virolaisten kanssa ei enää sinällään ole yhtä tärkeää.

Cultura-säätiön selvityksessä puolestaan havaittiin, että suomalaiseen yhteiskuntaan hyvin kotoutuneet venäjänkieliset suhtautuvat varovasti venäjänkielisiin järjestöihin. Tämän arveltiin johtuvan maailmankatsomuksellisista eroista, kuten järjestöjen konservatiivisuudesta ja sulkeutuneisuudesta. (Varjonen ym. 2017, 64.) Maahan muuttaneiden omat järjestöt eivät siten itsestään selvästi tue poliittista osallistumista uudessa kotimaassa, ja tämä on havaittu myös kansainvälisissä tutkimuksessa (esim. Morales ja Pilati 2011).

Suomeen muuttaneiden kokemalla syrjinnällä voidaan olettaa olevan vaikutusta siihen, kuinka tiiviisti he identifioituvat Suomeen ja kokevat maan poliittiset instituutiot omikseen. Erityisesti somalialaiset ja venäläiset, mutta myös virolaiset ovat kokeneet Suomessa etniseen taustaan perustuvaa syrjintää (Mubarak ym. 2015; Puuronen 2011; Rask ym. 2020). Ruotsalaisten kokemasta syrjinnästä ei ole juurikaan tutkimustietoa. Riikinruotsalaisia Suomessa tutkinut Östen Wahlbeck (2015) on kuitenkin havainnut, että myös hienovaraisemmat kulttuuriset jännitteet suomalaisten ja ruotsalaisten välillä voivat - ainakin jossain määrin - muodostua osallisuutta 
heikentäviksi symbolisiksi ja sosiaalisiksi rajoiksi. Näin on huolimatta siitä, että lähtökohtaisesti Suomi ja Ruotsi ovat yhteiskuntina hyvin samankaltaisia, eivätkä Ruotsista Suomeen muuttavat välttämättä odota kohtaavansa ongelmia sopeutumisen suhteen.

Moni tutkimus tukee käsitystä siitä, että sosiaalista asemaa vahvemmin maahanmuuttotaustaisten vähemmistöjen äänestämistä selittää eri etnisten ryhmien sisäinen koheesio kuten se, missä määrin ryhmän jäsenet tuntevat keskinäistä yhteenkuuluvuuden tunnetta. Toisin sanoen etnisiin vähemmistöihin kuuluvat käyvät äänestämässä ennen kaikkea voidakseen ilmaista oman identifioitumisensa osana tiettyä ryhmää ja osoittaakseen sille solidaarisuutta. (Barreto 2010; Bergh ja Bjørklund 2011; Winkler 1993.) Tarkasteltavista ryhmistä somalialaistaustaisten asuminen on muita ryhmiä keskittyneempää samoihin kuntiin ja osin myös samoille asuinalueille (Dhalmann 2011; Hirvonen 2019). Siten voidaan ajatella, että kommunikointi omalla kielellä ja samaan etniseen ryhmään kuuluvien kanssa on heidän osaltaan mahdollista usein, mikä puolestaan saattaa tukea voimakkaan ryhmäidentiteetin muodostumista ja siten myös äänestämistä (Cho ym. 2006; Pitkänen ym. 2019a, 41; Vermeulen ym. 2020). Somalialaisten vahvasta ryhmäidentiteetistä kertonee myös se, että pääkaupunkiseudun viittä suurinta vieraskielistä ryhmää tutkinut Ville Pitkänen kollegoineen (2019b, 53) havaitsi, että somalinkieliset luottivat kantaväestöä enemmän omasta ja sukunsa lähtömaasta kotoisin oleviin Suomessa asuviin ihmisiin, siinä missä venäjän- ja vironkieliset luottivat kantasuomalaisiin enemmän kuin omiin maannaisiin- tai miehiinsä. On kuitenkin huomattava, että vaikka somalialaistaustainen yhteisö näyttää muihin ryhmiin verrattuna yhtenäisemmältä, sitä kuitenkin jakavat esimerkiksi klaanisuhteet ja lähtömaahan liittyvät identiteetit sekä Suomeen muuton ajankohta, joka määrittelee millaista elämä lähtömaassa on ollut ja kuinka paljon kokemusta suomalaisesta yhteiskunnasta on ehtinyt kertyä (Mubarak ym. 2015; Pirkkalainen 2013; Tiilikainen ja Hassan Mohamed 2013).

\section{TUTKIMUKSEN HYPOTEESIT, AINEISTO JA MENETELMÄT}

Tutkimuksen empiirisessä osiossa tarkastellaan Suomeen muuttaneiden venäläis-, virolais-, somalialais- ja ruotsalaistaustaisten äänestysaktiivisuutta vuoden 2017 kuntavaaleissa, sekä sitä, miten sukupuoli, ikä, ammattiasema, henkilökohtaiset tulot, siviilisääty ja kansalaisuus siihen vaikuttivat. Analyysissa testataan seuraavia, aiempaan tutkimukseen pohjautuvia hypoteeseja.

Poliittinen sosialisaatio demokraattisessa maassa vahvistaa äänestämisen kokemista kansalaisvelvollisuutena ja siten myös nostaa äänestysaktiivisuutta Suomessa. Virolaisten kohdalla on huomioitava maan neuvostohistorian vaikutukset, vaikka Viro nykyään on demokratia. Täten:

H1a: Demokraattisesta maasta muuttaneiden ruotsalaisten äänestystodennäköisyys on eidemokraattisesta maasta muuttaneita somali- ja venäläistaustaisia korkeampi.

H1b: Virolaisten äänestysaktiivisuus ei ole samalla tasolla kuin ruotsalaisten.

Venäläis-, virolais- ja ruotsalaistaustaiset naiset äänestävät omissa lähtömaissaan miehiä aktiivisemmin ja eron voidaan olettaa siirtyvän Suomeen. Somalialaistaustaisten osalta ei ole saatavissa 
tietoja sukupuolten äänestysaktiivisuudesta, mutta mediatietojen mukaan naiset rekisteröityivät miehiä ahkerammin äänestäjiksi Somalian vuoden 2016 parlamenttivaaleissa. Näin ollen:

H2: Naiset äänestävät miehiä aktiivisemmin kaikissa tarkasteltavissa ryhmissä.

Iällä on lievempi yhteys äänestämiseen maahanmuuttotaustaisten kuin syntyperäisten äänioikeutettujen keskuudessa, koska toisessa poliittisessa kontekstissa varttuneilla äänestäjillä vaalitilanne on uusi iästä riippumatta:

H3: Iän ja äänestysaktiivisuuden välillä ei ole voimakkaan lineaarista positiivista yhteyttä ulkomaalaistaustaisten äänioikeutettujen keskuudessa.

Äänestysaktiivisuus on sitä korkeampi, mitä turvatummassa yhteiskunnallisessa asemassa maahan muuttanut on:

H4: Korkeampi tulotaso (H4a), korkeampi ammattiasema (H4b) ja/tai avioliitto (H4c) lisäävät ulkomaalaistaustaisten äänioikeutettujen todennäköisyyttä äänestää.

Äänestysaktiivisuus on sitä korkeampi, mitä tiiviimmät siteet suomalaiseen yhteiskuntaan yksilöllä on:

H5: Äänestysaktiivisuus on korkeampaa Suomen kansalaisuuden saaneilla verrattuna ei-kansalaisiin (H5a) sekä Suomen kansalaisen kanssa naimisissa olevilla ulkomaalaistaustaisilla (H5b).

Tutkimusaineisto pohjautuu oikeusministeriön ylläpitämään sähköiseen äänioikeusrekisteriin, joka kattoi vuoden 2017 kuntavaaleissa yhteensä 1377450 äänioikeutettua. Tilastokeskuksessa sähköisen äänioikeusrekisterin perustietoihin on yhdistetty henkilötunnuksen avulla paitsi erilaisia äänioikeutettujen sosioekonomista asemaa kuvaavia muuttujia (tiedot ovat peräisin vuosilta 2015 ja 2016) myös tieto heidän syntyperästään. Suurimpien ulkomaalaistaustaisten ryhmien osalta Tilastokeskus on luovuttanut myös tiedot äänioikeutettujen kansalaisuudesta, synnyinmaasta ja äidinkielestä. Tilastokeskus luokittelee suomalaistaustaisiksi kaikki ne henkilöt, joilla vähintään toinen vanhemmista on syntynyt Suomessa. Ulkomaalaistaustaisia puolestaan ovat ne henkilöt, joiden molemmat vanhemmat tai ainoa tiedossa oleva vanhempi on syntynyt ulkomailla. Syntyperämuuttuja sisältää myös tiedon siitä, onko henkilö ulkomailla syntynyt suomalaistaustainen tai Suomessa syntynyt ulkomaalaistaustainen. Tässä artikkelissa tarkastellaan vain ulkomailla syntyneitä ulkomaalaistaustaisia eli itse Suomeen muuttaneita. Toisin sanoen analyysi ei siis huomioi ulkomailla syntyneiden henkilöiden Suomessa syntyneitä lapsia eli niin kutsuttua "toista polvea", joista suurin osa on vielä alaikäisiä eikä siten toistaiseksi äänioikeutettuja (Tilastokeskus 2020a).

Äänioikeutetut on luokiteltu venäläis-, virolais-, somalialais- ja ruotsalaistaustaisiksi Tilastokeskuksen syntyperäluokituksen (ulkomailla syntynyt ulkomaalaistaustainen) sekä henkilöiden väestötietojärjestelmään rekisteröidyn äidinkielen ja/tai syntymämaan perusteella. Luokittelu ei 
ole ongelmaton, sillä väestötietojärjestelmään on mahdollista rekisteröidä vain yksi äidinkieli ja rekisteriin valittavaan kielen valintaan voi vaikuttaa moni yksilöllinen seikka. Myös kaksois- ja kolmoiskansalaiset rekisteröidään vain Suomen kansalaisiksi (Saukkonen 2020, 25-26). Syntyperä-, äidinkieli- ja taustamaamuuttujien yhdistely ryhmien luokittelussa johtaa tilanteeseen, jossa osan ryhmien kohdalla olisi mielekkäämpää puhua kieliryhmästä taustamaaryhmän sijaan. Alla on pyritty esittelemään mahdollisimman täsmällisesti se, miten vertailtavat ryhmät on rekisteriaineistossa muodostettu.

- Venäläistaustaisiksi luetaan kaikki ne ulkomailla syntyneet ulkomaalaistaustaiset äänioikeutetut, jotka ovat ilmoittaneet äidinkielekseen venäjän lukuun ottamatta heitä, joiden synnyinmaa on Viro ( $n=14$ 303). Tämä tarkoittaa, että mukana on henkilöitä myös esimerkiksi Baltian maista ja Ukrainasta, joskin heidän osuutensa voidaan arvioida kohtuullisen pieneksi. Tilastokeskuksen (2020c) mukaan vuosina 1992-2017 yhteensä 75 prosenttia Suomeen muuttaneista venäjänkielisistä muutti Suomeen Venäjältä ja 16 prosenttia Virosta. Venäläistaustaisten osalta luokitus on muita ryhmiä laveampi siitä syystä, ettei yksittäisen äänioikeutetun synnyinmaata ole mahdollista tarkalleen selvittää. Näin ollen venäläistaustaisten osalta kyse on siis pikemminkin Suomen venäjänkielisistä. Esimerkiksi Neuvosto-Viron alueella syntyneet venäjänkieliset luetaan tässä aineistossa venäläistaustaisiksi siinä missä Neuvostoliiton hajoamisen jälkeen (uudelleen)itsenäistyneessä Virossa syntyneet venäjänkieliset äänioikeutetut luetaan kuitenkin virolaistaustaisiksi.

- Virolaistaustaisiksi on luokiteltu kaikki ne ulkomailla syntyneet ulkomaalaistaustaiset äänioikeutetut, joiden äidinkieli on viro tai joiden syntymämaa on Viro. Käytännössä virolaistaustaisia ovat siis äidinkieleltään vironkieliset sekä Neuvostoliiton hajoamisen jälkeen Virossa syntyneet venäjänkieliset ( $\mathrm{n}=14346)$.

- Somalialaistaustaisiksi on luokiteltu ne ulkomailla syntyneet ulkomaalaistaustaiset äänioikeutetut, joiden äidinkieli on somali ( $\mathrm{n}=1$ 699). Heistä 1667 on syntynyt Somaliassa.

- Ruotsalaistaustaisiksi on luokiteltu ne ulkomailla syntyneet ulkomaalaistaustaiset, joiden syntymämaa on Ruotsi $(n=734)$. Näin esimerkiksi Ruotsissa syntyneet mutta vanhempien syntyperän vuoksi ulkomailla syntyneiksi suomalaistaustaisiksi laskettavat (paluumuuttajat) eivät kuulu kohdejoukkoon. Suomalaistaustaisten isovanhempien lapset puolestaan kuuluvat. Ruotsalaistaustaisten osalta käytetään vain syntymämaa-muuttujaa, sillä Suomessa useilla muillakin ulkomailla syntyneillä on pätevät perustelut rekisteröidä ruotsi äidinkielekseen esimerkiksi muuttaessaan maamme ruotsinkielisille alueille. Ruotsalaistaustaisista 504:llä rekisteröity äidinkieli on ruotsi, 198:1la suomi ja 32:1la muu kieli.

- Analyysissa verrataan neljän ulkomailla syntyneen ryhmän äänestysaktiivisuutta ja siihen vaikuttaneita sosioekonomiseen taustaan liittyviä tekijöitä paitsi ryhmien välillä myös verrattuna Suomessa syntyneisiin suomalaistaustaisiin äänestäjiin, joiden rekisteröity äidinkieli on suomi tai ruotsi ( $\mathrm{n}=1290251)$.

Analyysimenetelmänä käytetään logistista regressioanalyysiä, jossa selitettävä muuttuja saa arvon 1 mikäli henkilö äänesti ja arvon 0 mikäli tämä jätti äänestämättä. Selittävinä muuttujina ovat äänioikeutettujen sukupuoli, ikä, ammattiryhmä, tulotaso (valtionveronalaiset henkilökohtaiset tulot), siviilisääty ja kansalaisuus, jotka kuvaavat paitsi yksilön sosioekonomista asemaa, 
myös heidän kiinnittymistään yhteiskuntaan (muuttujien luokat esitetty taulukossa 1). Aineistoon sisältyvää koulutusmuuttujaa ei ole huomioitu, sillä tutkintorekisterin tiedot ulkomaalaistaustaisen väestön osalta olivat ainakin vielä vuonna 2017 hyvin puutteelliset (Witting 2019). Muuttujien valinta perustui ennen kaikkea siihen, miltä osin rekisteritiedot olivat riittävän kattavat kaikkien tarkasteltavien ryhmien osalta eikä puuttuvien havaintojen määrä noussut liian suureksi.

Analyysissa hyödynnetään tilastollista testausta, sillä vaikka rekisteriaineisto kattaa hyvin suuren osan kaikista äänioikeutetuista, ulkomaalaistaustaisten ryhmien osalta se ei kuitenkaan ole yhtä kattava kuin suomalaistaustaisten, minkä vuoksi estimaatit voivat näiden ryhmien osalta olla epätarkkoja. Sähköinen äänioikeusrekisteri on käytössä eri kunnissa ja äänestysalueilla vaihtelevasti, sillä sen käyttöönotto on vapaaehtoista ja riippuu esimerkiksi vaalilautakunnan halukkuudesta ottaa se käyttöön (Huotarinen ym. 2020, 46-47). Esimerkiksi Helsingissä, missä myös suurin osa Suomen somalialaistaustaisesta väestöstä asuu, sähköinen äänioikeusrekisteri oli käytössä vain muutamilla alueilla.

\section{TULOKSET}

Taulukko 1 näyttää äänioikeutettujen suhteellisen osuuden ja lukumäärän kussakin tarkasteltavassa ryhmässä kunkin selittävän muuttujan luokassa. Taulukosta havaitaan, että venäläistaustaisten äänioikeutettujen ryhmässä on selvästi enemmän naisia kuin miehiä (62\% vs. 38 \%). Ruotsalaistaustaisissa puolestaan miehiä on hieman enemmän kuin naisia. Muissa ryhmissä suhde on lähempänä 50-50-suhdetta. Ikäjakauma osoittaa, että somalialaistaustaiset äänioikeutetut ovat hyvin nuoria muihin ryhmiin verrattuna. Heistä lähes 40 prosenttia on alle 30 -vuotiaita. Venäläis-, virolais- ja somalialaistaustaisten keskuudessa erityisesti työikäisten osuus on suurempi kuin suomalais- ja ruotsalaistaustaisen väestön keskuudessa.

Ammattiaseman osalta merkittävää on eritoten työntekijäammattien korostuminen virolaistaustaisten keskuudessa ja "muu"-kategorian korostuminen somalialaistaustaisten osalta. "Muu"-kategoria pitää sisällään ennen kaikkea työttömät ja asevelvollisuuttaan suorittavat, mutta myös ne, joiden tilanne on Tilastokeskukselle tuntematon. Somaleiden keskuudessa on erityisen paljon opiskelijoita, mikä liittyy nuorten suureen osuuteen ryhmässä. Ruotsalaistaustaisten ammattitausta puolestaan on varsin yhtenevä suomalaistaustaisten ammattitaustan kanssa.

Tulotason osalta huomattavaa on, että yli neljä viidestä somalialaistaustaisesta ja puolet venäläistaustaisista sijoittui alimpaan tulodesiiliin eli heidän verotettava ansiotulonsa vuodessa oli korkeintaan 14000 euroa. Ruotsalais- ja virolaistaustaisten tulotaso muistuttaa huomattavasti enemmän suomalaistaustaisten vastavaa. Siviilisäädyn osalta huomio kiinnittyy naimattomien suureen osuuteen virolais- ja somalialaistaustaisten keskuudessa, mikä liittyy muita ryhmiä nuorempaan ikärakenteeseen. Venäläis- ja ruotsalaistaustaisten keskuudessa naimisissa olevien osuus on suurinta, mikä heijastaa perhesyihin liittyvän maahanmuuton yleisyyttä kyseisissä ryhmissä. Kansalaisuuden saaneiden osuus on suurin venäläis- ja somalialaistaustaisten keskuudessa: heistä puolella on Suomen kansalaisuus. Virolaisista kansalaisuus on vain yhdellä kymmenestä, mikä osaltaan kuvastaa virolaisten Suomessa asumisen tilapäisyyttä. 
Taulukko 1. Äänioikeutettujen jakaumat sähköisessä äänioikeusrekisterissä etnisen taustan ja selittävien muuttujien mukaan, \% (n)

\begin{tabular}{|c|c|c|c|c|c|}
\hline & Suomalaistaustaiset & Venäläistaustaiset & Virolaistaustaiset & Somalialaistaustaiset & Ruotsalaistaustaiset \\
\hline \multicolumn{6}{|l|}{ Sukupuoli } \\
\hline Mies & $48,7(628058)$ & $37,9(5417)$ & $50,1(7$ 184) & $50,9(864)$ & $56,3(413)$ \\
\hline Nainen & $51,3(662193)$ & $62,1(8886)$ & $49,9(7162)$ & $49,2(835)$ & $43,7(321)$ \\
\hline Yht. & 100 (1 290 251) & $100(14303)$ & $100(14346)$ & 100 (1 699) & $100(734)$ \\
\hline \multicolumn{6}{|l|}{ Ikäryhmä } \\
\hline $18-29$ & $17,0(218942)$ & $16,4(2347)$ & $17,9(2562)$ & $38,0(646)$ & $13,9(102)$ \\
\hline $30-39$ & $14,3(184068)$ & $24,2(3457)$ & $31,4(4502)$ & $27,8(472)$ & $14,9(109)$ \\
\hline $40-49$ & $14,2(183151)$ & $21,7(3$ 101) & $24,6(3533)$ & $17,1(291)$ & $16,9(124)$ \\
\hline $50-59$ & $16,7(215409)$ & $20,0(2864)$ & $17,7(2533)$ & $11,2(190)$ & $14,7(108)$ \\
\hline $60-69$ & $17,6(227276)$ & $12,4(1770)$ & $7,1(1020)$ & $3,9(67)$ & $12,0(88)$ \\
\hline $70-$ & $20,3(261405)$ & $5,3(764)$ & $1,4(196)$ & $1,9(33)$ & $27,7(203)$ \\
\hline Yht. & 100 (1 290251) & $100(14303)$ & $100(14346)$ & 100 (1 699) & $100(734)$ \\
\hline \multicolumn{6}{|l|}{ Ammattiasema } \\
\hline Yrittäjät (ml. maa- ja metsätalousyrittäjät) & $5,2(66594)$ & $4,7(666)$ & $6,3(853)$ & $0,4(6)$ & $5,0(34)$ \\
\hline Ylemmät toimihenkilöt & $10,8(139170)$ & $8,0(1134)$ & $4,1(558)$ & $2,7(46)$ & $11,2(77)$ \\
\hline Alemmat toimihenkilöt & $19,4(250497)$ & $14,5(2064)$ & $11,4(1556)$ & $6,0(102)$ & $13,7(94)$ \\
\hline Työntekijät & $14,7(189821)$ & $21,3(3032)$ & $45,4(6185)$ & $11,5(194)$ & $11,8(81)$ \\
\hline Opiskelijat & $7,0(90293)$ & $12,1(1725)$ & $6,3(860)$ & $25,4(431)$ & $4,7(32)$ \\
\hline Eläkeläiset & $31,8(409536)$ & $9,7(1380)$ & $4,0(541)$ & $5,2(88)$ & $35,3(242)$ \\
\hline $\begin{array}{l}\text { Työttömät / ase- / siviilipalveluksessa } \\
\text { olevat / muut / tuntematon * }\end{array}$ & $11,1(143215)$ & $29,8(4254)$ & $22,5(3066)$ & $48,9(828)$ & $18,4(126)$ \\
\hline Yht. & $100(1289126)$ & $100(14255)$ & $100(13619)$ & $100(1695)$ & $100(686)$ \\
\hline \multicolumn{6}{|l|}{ Henkilökohtaiset tulot e/v } \\
\hline 1. desiili: $0-14000$ & $26,2(334355)$ & $49,6(6700)$ & $30,2(3904)$ & $81,3(1319)$ & $27,8(184)$ \\
\hline 2. desiili: $15000-25000$ & $24,8(316831)$ & $20,1(2716)$ & $26,1(3375)$ & $9,7(157)$ & $27,9(185)$ \\
\hline 3. desiili: $26000-37000$ & $23,7(302562)$ & $18,3(2466)$ & $26,0(3365)$ & $5,6(91)$ & $23,5(156)$ \\
\hline 4. desiili: $38000-$ & $25,2(321923)$ & $12,0(1618)$ & $17,7(2288)$ & $3,4(55)$ & $20,8(138)$ \\
\hline Yht. & 100 (1 275 671) & $100(13500)$ & 100 (12 932) & $100(1622)$ & $100(663)$ \\
\hline \multicolumn{6}{|l|}{ Siviilisääty } \\
\hline Naimaton & $35,4(456919)$ & $23,0(3285)$ & $50,5(7242)$ & $38,4(653)$ & $28,3(204)$ \\
\hline Naimisissa/asumusero & $45,1(581477)$ & $57,2(8181)$ & $30,5(4372)$ & $43,6(740)$ & $52,6(380)$ \\
\hline Eronnut & $12,8(165295)$ & $16,6(2368)$ & $18,1(2589)$ & $15,7(267)$ & $14,3(103)$ \\
\hline Leski & $6,7(86560)$ & $3,3(469)$ & $1,0(143)$ & $2,3(39)$ & $4,9(35)$ \\
\hline Yht. & $100(1290251)$ & $100(14303)$ & $100(14346)$ & 100 (1 699) & $100(722)$ \\
\hline \multicolumn{6}{|l|}{ Kansalaisuus } \\
\hline Suomen kansalainen & $99,9(1289074)$ & $49,8(7$ 184) & $10,9(1557)$ & $48,9(831)$ & $41,0(301)$ \\
\hline Muu kansalaisuus & $0,1(1177)$ & $50,2(7119)$ & $89,2(12789)$ & $51,1(868)$ & $59,0(433)$ \\
\hline Yht. & 100 (1 290 251) & 100 (14 303) & 100 (14346) & 100 (1 699) & $100(734)$ \\
\hline
\end{tabular}

* Työttömäksi luettujen määrä tähän kategoriaan luokitelluissa suomalaistaustaisissa 104101 (72,7 \%), venäläistaustaisissa 2973 (69,9\%), virolaistaustaisissa 1890 (61,6\%), somalialaistaustaisissa 432 (52,2\%) ja ruotsalaistaustaisissa $58(46,0 \%)$. 
Logistisen regressioanalyysin tulokset esitetään taulukoissa 2 ja 3 siten, että äänestämisen todennäköisyyttä on tarkasteltu kunkin ryhmän kohdalla erikseen. Taulukossa 2 esitetään logistisen regressioanalyysin tulokset niin kutsuttujen vetosuhteiden (odds ratio) avulla. Eri ryhmien vetosuhteita ei voi verrata toisiinsa. Sen sijaan voidaan katsoa, mitkä selittävät muuttujat nousevat tilastollisesti merkitseviksi eri ryhmissä. Suomalaistaustaisten määrä aineistossa tosin on niin suuri, että pienetkin erot tulevat tilastollisesti merkitseviksi. Taulukosta 3 nähdään paitsi todelliset äänestysprosentit vertailtavissa ryhmissä myös niin kutsutut arvioidut äänestysprosentit asteikolla nollasta sataan. Arvioidut äänestysprosentit on laskettu Stata-ohjelman margins-komentoa apuna käyttäen taulukossa 2 esitetyistä logistisista regressioanalyyseistä (average adjusted predictions). Niiden avulla on mahdollista arvioida eri taustamuuttujien vaikutuksen mittakaavaa äänestämisen todennäköisyyteen, sillä ne esittävät äänestystodennäköisyyden kunkin muuttujan luokassa muiden sosiaaliseen taustaan liittyvien tekijöiden ollessa kontrolloituina. 
Taulukko 2. Äänestystodennäköisyyteen vaikuttavat demografiset ja sosioekonomiset taustatekijät. Logistinen regressioanalyysi. Vetosuhde (odds ratio) ja sulkeissa keskivirhe

\begin{tabular}{|c|c|c|c|c|c|}
\hline & Suomalaistaustaiset & Venäläistaustaiset & Virolaistaustaiset & Somalialaistaustaiset & Ruotsalaistaustaiset \\
\hline Nainen (ref. mies) & $1,196(, 005)^{* * *}$ & $1,352(, 068)^{* * *}$ & $1,601(, 106)^{* * *}$ & ,913 $(, 099)$ & $1,389(, 264)$ \\
\hline \multicolumn{6}{|l|}{ Ikäryhmä (ref. 18-29) } \\
\hline $30-39$ & $1,126(, 009)^{* * *}$ & $1,386(, 128)^{* * *}$ & $1,620(, 193)^{* * *}$ & $1,383(, 196)^{*}$ & $2,790(1,124)^{*}$ \\
\hline $40-49$ & $1,360(, 011)^{* * *}$ & $1,649(, 161)^{* * *}$ & $2,339(, 283)^{* * *}$ & $1,581(, 271)^{* *}$ & $4,040(1,643)^{* *}$ \\
\hline $50-59$ & $1,728(, 014)^{* * *}$ & $2,206(, 215)^{* * *}$ & $3,084(, 377)^{* * *}$ & $1,145(, 222)$ & $3,929(1,660)^{* *}$ \\
\hline $60-69$ & $2,839(, 026)^{* * *}$ & $2,654(, 284)^{* * * *}$ & $3,783(, 538)^{* * * *}$ & $2,061(, 673)^{*}$ & $6,535(3,152)^{* * *}$ \\
\hline $70-$ & $2,783(, 032)^{* * *}$ & $2,747(, 430)^{* * *}$ & $3,786(, 953)^{* * *}$ &, $482(, 235)$ & $4,572(2,463)^{* *}$ \\
\hline \multicolumn{6}{|l|}{ Ammattiasema (ref. työntekijät) } \\
\hline Yrittäjät (ml. maa- ja metsätalousyrittäjät) & $1,718(, 017)^{* * *}$ & $1,330(, 152)^{*}$ & $1,297(, 167)^{*}$ & $1,231(1,094)$ & $5,008(2,413)^{* *}$ \\
\hline Ylemmät toimihenkilöt & $2,790(, 024)^{* * *}$ & $2,308(, 204)^{* * *}$ & $4,479(, 515)^{* * *}$ & ,931 (,319) & $5,861(2,255)^{* * *}$ \\
\hline Alemmat toimihenkilöt & $1,510(, 010)^{* * *}$ & $1,505(, 113)^{* * *}$ & $1,848(, 164)^{* * *}$ & $1,053(, 268)$ & $2,762(, 967)^{* *}$ \\
\hline Opiskelijat & $2,169(, 021)^{* * *}$ & $1,660(, 166)^{* * *}$ & $1,756(, 253)^{* * *}$ & $1,491(, 317)$ & $6,617(3,625)^{* *}$ \\
\hline Eläkeläiset & $1,351(, 012)^{* * *}$ & $1,822(, 217)^{* * *}$ & $1,667(, 276)^{* *}$ & $1,511(, 541)$ & $2,967(1,392)^{*}$ \\
\hline Muut / tuntematon & $1,225(, 010)^{* * *}$ & $1,337(, 099)^{* * *}$ & $1,324(, 117)^{* *}$ & $1,329(, 258)$ & $2,000(, 695)^{*}$ \\
\hline \multicolumn{6}{|l|}{$\begin{array}{l}\text { Henkilökohtaiset tulot e/v } \\
\text { (ref. 0-14 000) }\end{array}$} \\
\hline $15000-25000$ & $1,433(, 008)^{* * *}$ & $1,149(, 075)^{*}$ & $1,055(, 092)$ & ,935 (,186) & $2,050(, 497)^{* *}$ \\
\hline $26000-37000$ & $1,843(, 012)^{* * *}$ & $1,074(, 080)$ & $1,138(, 106)$ & $1,106(, 288)$ & $2,849(, 790)^{* * *}$ \\
\hline $38000-$ & $2,273(, 016)^{* * *}$ & $1,168(, 100)$ & $1,146(, 118)$ & $1,391(, 452)$ & $2,146(, 612)^{*}$ \\
\hline \multicolumn{6}{|l|}{ Siviilisääty (ref. naimaton) } \\
\hline Naimisissa/asumusero & $1,760(, 009)^{* * *}$ & $1,247(, 089)^{* *}$ & $1,565(, 107)^{* * *}$ & $1,564(, 209)^{* *}$ & $1,212(, 287)$ \\
\hline Eronnut & $930(, 006)^{* * * *}$ & ,904 (,079) & ,972 $(, 084)$ & $1,626(, 284)^{* *}$ &, $509(, 156)^{*}$ \\
\hline Leski & ,767 $(, 007)^{* * *}$ & ,778 (,107) & $1,491(, 316)$ & ,912 (,332) &, $525(, 238)$ \\
\hline $\begin{array}{l}\text { Suomen kansalainen } \\
\text { (ref. muu kansalaisuus) }\end{array}$ & $2,798(, 180)^{* * *}$ & $2,130(, 102)^{* * *}$ & $3,224(, 227)^{* * *}$ & ,969(,105) & $1,842(, 372)^{* *}$ \\
\hline Vakio & $0,103(0,007)^{* * *}$ & $0,049(0,005)^{* * *}$ & $0,022(0,003)^{* * *}$ & $0,689(0,145)$ & $0,046(0,022)^{* * *}$ \\
\hline$N$ & 1275671 & 13500 & 12932 & 1622 & 662 \\
\hline Nagelkerke $\mathbf{R}^{2}$ & 0,149 & 0,092 & 0,165 & 0,046 & 0,215 \\
\hline
\end{tabular}

${ }^{\star} \mathrm{p}<, 05 ;{ }^{*} \mathrm{p}<, 01 ;{ }^{* *} \mathrm{p}<, 001$ 
Taulukko 3. Todellinen ja arvioitu äänestysprosentti etnisen taustan ja sosioekonomisen aseman mukaan

\begin{tabular}{|c|c|c|c|c|c|c|c|c|c|c|}
\hline & \multicolumn{2}{|c|}{ Suomalaistaustaiset } & \multicolumn{2}{|c|}{ Venäläistaustaiset } & \multicolumn{2}{|c|}{ Virolaistaustaiset } & \multicolumn{2}{|c|}{ Somalialaistaustaiset } & \multicolumn{2}{|c|}{ Ruotsalaistaustaiset } \\
\hline & $\begin{array}{l}\text { Tod. } \\
\text { ään-\% }\end{array}$ & $\begin{array}{l}\text { Arv. } \\
\text { ään-\% }\end{array}$ & $\begin{array}{l}\text { Tod. } \\
\text { ään-\% }\end{array}$ & $\begin{array}{l}\text { Arv. } \\
\text { ään-\% }\end{array}$ & $\begin{array}{l}\text { Tod. } \\
\text { ään-\% }\end{array}$ & $\begin{array}{l}\text { Arv. } \\
\text { ään-\% }\end{array}$ & $\begin{array}{l}\text { Tod. } \\
\text { ään-\% }\end{array}$ & $\begin{array}{l}\text { Arv. } \\
\text { ään-\% }\end{array}$ & $\begin{array}{l}\text { Tod. } \\
\text { ään-\% }\end{array}$ & $\begin{array}{l}\text { Arv. } \\
\text { ään-\% }\end{array}$ \\
\hline Kaikki & 59,6 & 59,9 & 20,7 & 21,7 & 11,1 & 12,1 & 56,7 & 57,6 & 52,0 & 55,4 \\
\hline \multicolumn{11}{|l|}{ Sukupuoli } \\
\hline Mies & 57,8 & 57,9 & 15,9 & 18,6 & 7,3 & 9,6 & 56,7 & 58,7 & 49,6 & 52,3 \\
\hline Nainen & 61,3 & 61,8 & 23,6 & 23,3 & 14,8 & 14,0 & 56,7 & 56,6 & 55,1 & 59,0 \\
\hline \multicolumn{11}{|l|}{ Ikäryhmä } \\
\hline-29 & 37,8 & 47,7 & 10,7 & 13,8 & 4,8 & 6,3 & 48,9 & 52,9 & 21,6 & 28,0 \\
\hline $30-39$ & 52,5 & 50,4 & 17,4 & 18,0 & 8,4 & 9,5 & 60,2 & 60,7 & 44,0 & 49,4 \\
\hline $40-49$ & 61,0 & 54,7 & 20,5 & 20,6 & 11,8 & 12,9 & 65,6 & 63,8 & 54,0 & 57,5 \\
\hline $50-59$ & 64,9 & 60,1 & 25,6 & 25,5 & 15,7 & 15,9 & 57,9 & 56,2 & 53,7 & 56,9 \\
\hline $60-69$ & 72,0 & 70,5 & 28,5 & 29,0 & 21,6 & 18,6 & 73,1 & 69,6 & 62,5 & 67,5 \\
\hline $70-$ & 66,9 & 70,1 & 30,0 & 29,7 & 28,1 & 18,6 & 39,4 & 35,4 & 65,0 & 60,2 \\
\hline \multicolumn{11}{|l|}{ Ammattiasema } \\
\hline Yrittääät (ml. maa- ja metsätalousyrittääät) & 64,5 & 63,4 & 20,3 & 20,4 & 10,4 & 11,2 & * & * & 64,7 & 67,5 \\
\hline Ylemmät toimihenkilöt & 78,0 & 72,9 & 32,3 & 30,2 & 35,1 & 28,1 & 52,2 & 49,7 & 68,8 & 70,4 \\
\hline Alemmat toimihenkilöt & 61,6 & 60,7 & 25,8 & 22,4 & 19,9 & 14,9 & 52,9 & 52,7 & 53,2 & 55,4 \\
\hline Työntekijät & 47,4 & 51,6 & 15,3 & 16,3 & 7,6 & 9,0 & 53,1 & 51,4 & 30,9 & 33,8 \\
\hline Opiskelijat & 43,5 & 68,1 & 14,7 & 24,0 & 9,9 & 14,3 & 55,9 & 60,9 & 40,6 & 72,6 \\
\hline Eläkeläiset & 65,8 & 58,2 & 29,9 & 25,7 & 25,0 & 13,8 & 56,8 & 61,2 & 65,3 & 56,9 \\
\hline $\begin{array}{l}\text { Työttömät / ase- / siviilipalveluksessa } \\
\text { olevat / muut / tuntematon }\end{array}$ & 44,9 & 56,1 & 18,6 & 20,5 & 9,2 & 11,4 & 58,5 & 58,2 & 39,7 & 48,4 \\
\hline \multicolumn{11}{|l|}{ Henkilökohtaiset tulot e/v } \\
\hline 1. desiili: 0-14000 & 45,4 & 50,3 & 20,0 & 20,7 & 11,2 & 11,4 & 57,9 & 57,4 & 40,2 & 42,5 \\
\hline 2. desiili: $15000-25000$ & 59,9 & 58,4 & 22,3 & 22,9 & 10,9 & 11,9 & 54,1 & 55,8 & 61,1 & 57,9 \\
\hline 3. desiili: $26000-37000$ & 63,3 & 63,9 & 22,1 & 21,8 & 12,1 & 12,6 & 56,0 & 59,8 & 61,5 & 64,6 \\
\hline 4. desiili: $38000-$ & 72,0 & 68,3 & 26,6 & 23,2 & 15,0 & 12,7 & 63,6 & 65,0 & 60,9 & 58,9 \\
\hline \multicolumn{11}{|l|}{ Siviilisääty } \\
\hline Naimaton & 44,9 & 55,2 & 12,5 & 20,0 & 7,0 & 10,4 & 47,8 & 51,0 & 38,7 & 56,1 \\
\hline Naimisissa/asumusero & 72,1 & 67,5 & 23,7 & 23,5 & 17,5 & 14,8 & 62,4 & 61,8 & 61,8 & 60,0 \\
\hline Eronnut & 57,4 & 53,5 & 20,9 & 18,5 & 10,5 & 10,1 & 63,3 & 62,7 & 43,7 & 41,9 \\
\hline Leski & 57,6 & 49,1 & 23,5 & 16,4 & 30,1 & 14,2 & 51,3 & 48,7 & 60,0 & 42,5 \\
\hline \multicolumn{11}{|l|}{ Kansalaisuus } \\
\hline Suomen kansalainen & 37,0 & 60,0 & 27,7 & 27,2 & 32,1 & 24,6 & 56,9 & 57,3 & 64,8 & 62,5 \\
\hline Muu kansalaisuus & 59,6 & 37,5 & 13,6 & 15,2 & 8,5 & 9,9 & 56,5 & 58,0 & 43,2 & 49,6 \\
\hline
\end{tabular}

Huom. Somalialaistaustaisissa oli lukumäärältään niin vähän yrittäjiä, ettei äänestysprosentin esittäminen ole kyseisen ryhmän osalta mielekästä. 
Taulukosta 3 nähdään, miten äänestysaktiivisuus vaihteli eri ryhmien välillä. Siinä missä 59,6 prosenttia äänioikeutetuista suomalaistaustaisista kävi äänestämässä, venäläistaustaisista äänioikeutetuista vaaliuurnille lähti vain viidennes $(20,7 \%)$ ja virolaistaustaisista joka kymmenes $(11,1 \%)$. Somalialais- ja ruotsalaistaustaisten äänestysaktiivisuus ei sen sijaan juurikaan poikennut suomalaistaustaisten äänestysaktiivisuudesta: ulkomailla syntyneistä somalialaistaustaisista äänioikeutetuista kävi äänestämässä 56,7 prosenttia ja ruotsalaistaustaisista 52 prosenttia. Hypoteesi 1a ei siten saa tukea, sillä epädemokraattisesta maasta Suomeen muuttaneiden somalialaistaustaisten äänestysaktiivisuus oli ulkomailla syntyneistä ryhmistä korkein. Myös epädemokraattisesta maasta muuttaneiden venäläistaustaisten äänestysaktiivisuus ylitti demokraattisesta maasta muuttaneiden virolaistaustaisten äänestysaktiivisuuden. Hypoteesi $1 \mathrm{~b}$ kuitenkin saa tukea, sillä vakiintuneemman demokraattisen järjestelmän piirissä varttuneet ruotsalaiset äänestivät nuoremman demokratian piirissä kasvaneita virolaisia selvästi useammin.

Naiset äänestivät miehiä aktiivisemmin kaikissa ryhmissä lukuun ottamatta somalialaistaustaisia, joiden keskuudessa naisten ja miesten äänestysaktiivisuus oli täsmälleen sama. Muissa tarkastelluissa ulkomaalaistaustaisissa ryhmissä erot naisten ja miesten välillä sen sijaan olivat selvästi suurempia, eivätkä ne katoa sosioekonominen taustan vakioinnilla. Naisten korkeampaa äänestysaktiivisuutta selittävät siten muut seikat kuin tulotasoon, ammattiasemaan ja siviilisäätyyn liittyvät tekijät. Hypoteesi 2 saa siis vahvistusta lukuun ottamatta somalialaistaustaisia, joiden keskuudessa taustamuuttujien vakiointi johtaa miesten äänestysaktiivisuuden nousuun.

Kaikkien muiden paitsi somalialaistaustaisten äänestysaktiivisuus nousi lineaarisesti iän myötä, joskin tasoittuen korkeimmassa ikäluokassa. Hypoteesi 3 ei saa tukea, sillä erot nuorempien ja vanhempien ikäluokkien välillä säilyvät suurina myös muiden taustamuuttujien vakioinnin jälkeen. Somalialaistaustaisten äänioikeutettujen osalta äänestysaktiivisuus sen sijaan oli selvästi korkeampaa 40-49- ja 60-69-vuotiaiden keskuudessa 50-59-vuotiaisiin verrattuna. Alle 30-vuotiaat äänestivät kaikissa ryhmissä selvästi muita ikäluokkia harvimmin, joskin taustamuuttujien vakioinnin jälkeen nuorimman ryhmän äänestystodennäköisyys nousee selvästi. Tärkeä havainto on, että ulkomailla syntyneet somalialaistaustaiset nuoret olivat selvästi suomalaistaustaisia nuoria aktiivisempia äänestäjiä (todellinen äänestysprosentti $48,9 \%$ vs. $37,8 \%)$.

Henkilökohtaisilla tuloilla oli suomalaistaustaisten keskuudessa lineaarinen yhteys äänestämiseen: matalimpaan tulodesiiliin kuuluvista alle puolet (45\%) äänesti siinä missä korkeimmassa tulodesiilissä äänestäneiden osuus oli seitsemän kymmenestä. Erot säilyvät vaikka muut taustamuuttujat vakioidaan. Ulkomaalaistaustaisten äänioikeutettujen keskuudessa yhteys ei ollut lineaarinen, vaikka erot matalimpaan ja korkeimpaan tuloluokkaan lukeutuvien välillä olivatkin selvät paremmin toimeentulevien hyväksi. Taulukosta 2 nähdään, ettei korkeampi tulotaso kasvata äänestämisen vetosuhdetta tilastollisesti merkitsevästi virolais- ja somalialaistaustaisten keskuudessa. Venäläistaustaisten keskuudessakaan yhteys ei ole suoraviivainen, sillä toiseen tulodesiiliin kuuluminen nostaa äänestämisen vetosuhdetta tilastollisesti merkitsevästi mutta tätä korkeampiin kuuluminen ei. Ruotsalaistaustaisten osalta äänestysaktiivisuus on taustamuuttujien vakioinnin jälkeen 58-65 prosenttia 2.-4. tulodesiileissä ja selvästi alhaisempi matalimmassa tulodesiilissä (42,5\%). Hypoteesi 4a korkeamman tulotason myönteisestä vaikutuksesta äänestämiseen saa siten tukea. 
Ammattiryhmän osalta huomataan, kuinka äänestysaktiivisuus oli lähes kaikissa ryhmissä matalinta työntekijäammateissa työskentelevien ja opiskelijoiden keskuudessa. Koska jälkimmäisten osalta tulokseen vaikuttaa pitkälti ryhmän nuori ikä, opiskelijoiden äänestystodennäköisyys nousee merkittävästi, kun taustamuuttujat vakioidaan. Kenties hätkähdyttävin tulos on, ettei ammattiasemalla näyttäisi olleen juuri lainkaan vaikutusta somalialaistaustaisten äänestämiseen. Heidän osaltaan äänestysaktiivisuus oli jopa korkeampaa työntekijöiden kuin toimihenkilöiden keskuudessa. Muissa tarkastelluissa ryhmissä työntekijäammateissa työskentelevien äänestysprosentti oli selvästi muita ammattiryhmiä matalampi, vaikka arvioitu äänestysprosentti nouseekin taustamuuttujien vakioinnin myötä. Hypoteesi 4b korkeamman ammattiaseman myönteisestä vaikutuksesta äänestysaktiivisuuteen saa tukea.

Naimisissa olevat äänestivät naimattomia aktiivisemmin kaikissa vertailluissa ryhmissä. Avioliiton suotuisa vaikutus säilyy, vaikka muut taustamuuttujat vakioidaan, joskaan tulos ei ruotsalaistaustaisten osalta ole tilastollisesti merkitsevä. Hypoteesi $4 \mathrm{c}$ saa siis tukea. Kun taustamuuttujat vakioidaan, avioerolla näyttäisi olevan voimakas kielteinen vaikutus äänestämiseen somalialaistaustaisia lukuun ottamatta.

Kansalaisuuden saamisella on aiemmissa tutkimuksissa havaittu olevan voimakas positiivinen yhteys äänestämiseen. Tämäkin tutkimus on muutoin täysin linjassa aiempien tutkimustulosten kanssa lukuun ottamatta somalialaistaustaisten muodostamaa poikkeusta. Heidän keskuudessaan muiden kuin Suomen kansalaisten äänestysaktiivisuus oli identtinen kansalaisuuden saaneiden äänioikeutettujen kanssa, mikä jälleen kerran korostaa somalialaistaustaisten poikkeuksellisuutta muihin ryhmiin nähden (taulukko 3). Somalialaisten muodostamaa poikkeusta lukuun ottamatta kansalaisuuden suotuisaa vaikutusta koskeva hypoteesi 5a saa siis tukea.

Taulukossa 4 tarkastellaan äänioikeutettujen jakaumia aineistossa etnisen taustan ja puolison kansalaisuuden mukaan. Kuten jo aiemmin todettiin, naimisissa olevien määrä oli selvästi suurempi venäläis- ja ruotsalaistaustaisten äänioikeutettujen keskuudessa virolais- ja somalialaistaustaisiin verrattuna. Tarkastelluista ryhmistä ruotsalaistaustaisille oli yleisintä olla avioliitossa Suomen kansalaisen kanssa. Avioliitossa olevista ruotsalaistaustaisista peräti 96 prosenttia oli naimisissa Suomen kansalaisen kanssa. Venäläistaustaisten osalta vastaava osuus oli 59 prosenttia ja somalialaistaustaisten 54 prosenttia. Virolaistaustaisista naimisissa olevista vain 33 prosenttia oli naimisissa Suomen kansalaisen kanssa.

Taulukko 5 näyttää todelliset ja arvioidut äänestysprosentit puolison kansalaisuuden mukaisissa ryhmissä. Arvioidut äänestysprosentit on laskettu vastaavasta logistisesta regressiosta kuin taulukossa 2, mutta tällä kertaa siviilisäätymuuttujana käytettiin kolmiluokkaista muuttujaa, joka kertoi, oliko äänioikeutettu naimisissa Suomen vai ulkomaan kansalaisen kanssa vai oliko niin, ettei hänellä ollut puolisoa (ks. liite 1). Tulokset osoittavat, että avioliitto Suomen kansalaisen kanssa lisäsi merkittävästi venäläis- ja virolaistaustaisten äänestysaktiivisuutta verrattuna siihen, jos puoliso oli ulkomaan kansalainen. Havainto ei kuitenkaan koske somalialaistaustaisia, joiden keskuudessa puolison kansalaisuudella ei ollut vaikutusta. Somalialaistaustaisten avioliitot suomalaistaustaisten kanssa tosin ovat harvinaisia verrattuna muihin ryhmiin, ja todennäköisesti Suomen kansalaisuuden omaava puoliso on itsekin somalialaistaustainen (Al-Sharmani ja Ismail 2017). Hypoteesi 5b saa tukea muiden kuin somalialaistaustaisten osalta. 
Taulukko 4. Äänioikeutettujen jakaumat sähköisessä äänioikeusrekisterissä etnisen taustan, siviilisäädyn ja puolison kansalaisuuden mukaan, \% (n)

\begin{tabular}{llllll}
\hline & Suomalaistaustaiset & Venäläistaustaiset & Virolaistaustaiset & Somalialaistaustaiset & Ruotsalaistaustaiset \\
\hline Puoliso Suomen kansalainen & $42,6(549381)$ & $30,3(4329)$ & $8,3(1196)$ & $16,1(273)$ & $47,4(348)$ \\
Puoliso ulkomaan kansalainen & $0,6(7691)$ & $21,4(3058)$ & $17,1(2459)$ & $13,4(228)$ & $2,0(15)$ \\
Ei puolisoa & $56,8(733177)$ & $48,4(6916)$ & $74,5(10691)$ & $70,5(1198)$ & $50,5(371)$ \\
\hline Yht. & $100(1290249)$ & $100(14303)$ & $100(14346)$ & $100(1699)$ & $100(734)$ \\
\hline
\end{tabular}

Taulukko 5. Todellinen ja arvioitu äänestysprosentti etnisen taustan ja puolison kansalaisuuden mukaan

\begin{tabular}{|c|c|c|c|c|c|c|c|c|c|c|}
\hline & \multicolumn{2}{|c|}{ Suomalaistaustaiset } & \multicolumn{2}{|c|}{ Venäläistaustaiset } & \multicolumn{2}{|c|}{ Virolaistaustaiset } & \multicolumn{2}{|c|}{ Somalialaistaustaiset } & \multicolumn{2}{|c|}{ Ruotsalaistaustaiset } \\
\hline & $\begin{array}{l}\text { Tod. } \\
\text { ään-\% }\end{array}$ & $\begin{array}{l}\text { Arv. } \\
\text { ään-\% }\end{array}$ & $\begin{array}{l}\text { Tod. } \\
\text { ään-\% }\end{array}$ & $\begin{array}{l}\text { Arv. } \\
\text { ään-\% }\end{array}$ & $\begin{array}{l}\text { Tod. } \\
\text { ään-\% }\end{array}$ & $\begin{array}{l}\text { Arv. } \\
\text { ään-\% }\end{array}$ & $\begin{array}{l}\text { Tod. } \\
\text { ään-\% }\end{array}$ & $\begin{array}{l}\text { Arv. } \\
\text { ään-\% }\end{array}$ & $\begin{array}{l}\text { Tod. } \\
\text { ään-\% }\end{array}$ & $\begin{array}{l}\text { Arv. } \\
\text { ään-\% }\end{array}$ \\
\hline Puoliso Suomen kansalainen & 73,2 & 68,7 & 30,8 & 27,6 & 38,5 & 24,6 & 64,1 & 62,7 & 64,9 & 62,2 \\
\hline Puoliso ulkomaan kansalainen & 56,6 & 56,9 & 15,9 & 18,6 & 9,9 & 10,6 & 65,8 & 64,2 & * & * \\
\hline Ei puolisoa & 49,5 & 53,7 & 16,4 & 18,5 & 8,3 & 10,1 & 53,2 & 55,2 & 41,5 & 49,3 \\
\hline
\end{tabular}

Huom. Ruotsalaistaustaisissa oli lukumäärältään niin vähän muun kuin Suomen kansalaisen kanssa naimisissa olevia, ettei äänestysprosentin esittäminen ole kyseisen ryhmän osalta mielekästä. 
Taulukko 6 tiivistää vielä tutkimuksen hypoteesit ja tulokset:

Taulukko 6. Tutkimuksen hypoteesit ja tulokset

\begin{tabular}{|c|c|}
\hline HYPOTEESI & TULOS \\
\hline $\begin{array}{l}\text { H1a: Demokraattisesta maasta muuttaneiden ruotsalaisten äänestysto- } \\
\text { dennäköisyys on ei-demokraattisesta maasta muuttaneita somalialais- } \\
\text { ja venäläistaustaisia korkeampi. }\end{array}$ & $\begin{array}{l}\text { Hypoteesi ei saa tukea, sillä somalialaistaustaisten äänestysaktiivisuus } \\
\text { oli yhtä korkea kuin ruotsalaistaustaisten. }\end{array}$ \\
\hline $\begin{array}{l}\text { H1b: Virolaisten äänestysaktiivisuus ei ole samalla tasolla kuin } \\
\text { ruotsalaisten. }\end{array}$ & Hypoteesi saa tukea. \\
\hline $\begin{array}{l}\text { H2: Naiset äänestävät miehiä aktiivisemmin kaikissa tarkasteltavissa } \\
\text { ryhmissä. }\end{array}$ & Somalialaistaustaisia lukuun ottamatta hypoteesi saa tukea. \\
\hline $\begin{array}{l}\text { H3: län ja äänestysaktiivisuuden välillä ei ole voimakkaan lineaa- } \\
\text { rista positiivista yhteyttä ulkomaalaistaustaisten äänioikeutettujen } \\
\text { keskuudessa. }\end{array}$ & $\begin{array}{l}\text { Hypoteesi ei saa tukea, sillä iän ja äänestysaktiivisuuden yhteys on } \\
\text { voimakkaan lineaarinen kaikissa ryhmissä somalialaistaustaisia lukuun } \\
\text { ottamatta. }\end{array}$ \\
\hline $\begin{array}{l}\text { H4: Korkeampi tulotaso (H4a), korkeampi ammattiasema (H4b) ja/ } \\
\text { tai avioliitto (H4c) lisäävät ulkomaalaistaustaisten äänioikeutettujen } \\
\text { todennäköisyyttä äänestää. }\end{array}$ & $\begin{array}{l}\text { Hypoteesit 4a ja 4b saavat muiden ryhmien osalta tukea lukuun } \\
\text { ottamatta somalialaistaustaisia, jotka äänestivät aktiivisesti muita } \\
\text { matalammasta tulotasostaan ja ammattiasemastaan huolimatta. } \\
\text { Hypoteesi 4c saa tukea kaikissa ryhmissä. }\end{array}$ \\
\hline $\begin{array}{l}\text { H5: Äänestysaktiivisuus on korkeampaa Suomen kansalaisuuden saa- } \\
\text { neilla verrattuna ei-kansalaisiin (H5a) sekä Suomen kansalaisen kanssa } \\
\text { naimisissa olevilla ulkomaalaistaustaisilla (H5b). }\end{array}$ & Somalialaistaustaisia lukuun ottamatta hypoteesi saa tukea. \\
\hline
\end{tabular}

\section{JOHTOPÄÄTÖKSET}

Tässä artikkelissa on tarkasteltu venäläis-, virolais-, somalialais- ja ruotsalaistaustaisten äänestysaktiivisuutta ja siihen vaikuttavia tekijöitä vuoden 2017 kuntavaaleissa. Tutkimuksen tulokset osoittavat, että sosioekonomisen taustan vaikutus äänestämiseen vaihteli paitsi eri etnisten ryhmien välillä, myös niiden sisällä. Keskeisin havainnoista on somalialaistaustaisten korkea osallistumisaste ja se, että he äänestivät aktiivisesti muita tarkasteltuja ryhmiä heikommasta tulotasostaan huolimatta. Tulos viittaa siihen, että somalialaisten äänestysaktiivisuuteen vaikuttivat ensisijaisesti muut kuin sosioekonomiseen asemaan nivoutuvat tekijät, jotka voivat liittyä esimerkiksi vahvaan ryhmäidentiteettiin ja sen muodostumista tukeviin rakenteisiin ryhmän sisällä (esim. Pirkkalainen ym. 2016). Tällaisia ovat esimerkiksi somalialaisten asutuksen keskittyminen ja siten muodostuvat tiiviit sosiaaliset verkostot. Kuntavaaleissa 2017 ehdolle asettui myös vahvoja somalialaistaustaisia ehdokkaita, jotka todennäköisesti onnistuivat mobilisoimaan oman yhteisönsä vaaliuurnille (Sipinen 2021). Aiemmassa tutkimuksessa on nostettu esiin myös somaliyhteisöä jakavia tekijöitä, kuten klaanit ja lähtömaahan liittyvät identiteetit (Mubarak ym. 2015; Pirkkalainen 2013; Tiilikainen ja Hassan Mohamed 2013). Jatkotutkimuksessa onkin syytä tarkastella, missä määrin nämä tekijät vaikuttavat ryhmän poliittiseen osallistumiseen. Paikallaan olisi myös toteuttaa vertaileva tutkimus somalidiasporien poliittisesta kiinnittymisestä eri maissa ja selvittää, näyttäytyvätkö somalialaistaustaiset yhtä aktiivisena ryhmänä myös muualla. 
Vertailluista ulkomaalaistaustaisista ryhmistä äänestysaktiivisuus oli matalinta virolaistaustaisten keskuudessa. Tätä selittävät todennäköisesti muita ryhmiä löyhemmät siteet suomalaiseen yhteiskuntaan, sillä moni virolainen ei aio jäädä pysyvästi asumaan Suomeen. Venäläistaustaisten tapauksessa matala äänestysinto puolestaan voi liittyä lähtömaassa omaksuttuihin politiikkakielteisiin asenteisiin, jotka ovat perua havaitusta vaalivilpistä, korruptiosta ja mahdollisesti jopa poliittisen vainon kohteeksi joutumisesta tai sen uhasta. Siinä missä somalialaistaustaiset poliitikot ovat olleet näkyvästi esillä suomalaisessa mediassa, virolais- ja venäläistaustaisia poliitikkoja ei julkisuudessa ole vastaavassa määrin näkynyt. Myös tällä voi olla vaikutusta virolais- ja venäläistaustaisten matalaan äänestysaktiivisuuteen. Erityisesti venäläistaustaisten äänestysintoa voi myös heikentää se, että moni suomalainen suhtautuu varauksellisesti venäläisten poliittiseen aktiivisuuteen Suomessa, mikä puolestaan on seurausta maiden välisistä historiallisista ja poliittisista jännitteistä (esim. Ronkainen 2009, 106-107). Esimerkiksi Suomen ja Venäjän kaksoiskansalaisista on maalattu kuvaa poliittisena ja kansalliseen turvallisuuteen liittyvänä uhkana, ja heidän lojaliteettiaan Suomelle on kyseenalaistettu (Kananen ja Ronkainen 2020).

Ruotsalaistaustaisten äänestysaktiivisuus Suomessa on verrattain korkeaa, mikä lienee seurausta maan demokratiakasvatuksesta ja -perinteistä, joiden vuoksi äänestämistä pidetään kiinteänä osana poliittista kansalaisuutta. Ruotsalaistaustaisten on myös mahdollisuus saada Suomen vaaleista tietoa omalla äidinkielellään. Onkin perusteltua syytä olettaa, että merkittäviltä osin ulkomaalaistaustaisten äänestysaktiivisuuteen vaikuttanee se, missä määrin heidän on mahdollista saada tietoa omasta äänioikeudestaan sekä vaaleista, puolueista ja ehdokkaista kielellä, jota he ymmärtävät. Monikielinen vaaliviestintä on toistaiseksi ollut pääasiassa ulkomaalaistaustaisten ehdokkaiden vastuulla (Sipinen 2021), mikä korostaa ulkomaalaistaustaisten ehdokkaiden edustuksen tärkeyttä puolueiden ehdokaslistoilla. Myös Suomeen muuttaneiden omat järjestöt ovat pyrkineet tiedottamaan kielivähemmistöjä vaaleista, esimerkkinä tällaisesta toiminnasta mainittakoon oikeusministeriön rahoittama ja Moniheli ry:n toteuttama iCounthanke.

Ulkomaalaistaustaisten äänestyskäyttäytymiseen ja yleisesti poliittiseen kiinnittymiseen vaikuttavista tekijöistä tarvitaan vielä paljon jatkotutkimuksia, sillä eri maista ja erilaisten poliittisten järjestelmien piiristä Suomeen muuttaneiden äänestämiseen vaikuttavat lukuisat eri tekijät, jotka liittyvät paitsi lähtömaahan myös siihen, miten suomalainen yhteiskunta on ottanut heidät vastaan. Tässä tutkimuksissa tarkastelu on rajautunut ainoastaan rekisteriaineiston sisältämiin tietoihin äänioikeutettujen sosiaalisesta taustasta. Ulkomaalaistaustaisten äänestysintoa selittävät kuitenkin lukuisat kognitiiviset ja asennepohjaiset muuttujat, joista saadaan tietoa ainoastaan kysymällä henkilöiltä itseltään. Tämä tarkoittaa, että jatkossa on syytä kartoittaa laajemmin myös eri ulkomaalaistaustaisten ryhmien asenteita politiikkaa ja poliittista osallistumista kohtaan. Tässä tutkimuksessa ei myöskään tarkasteltu Suomessa syntyneiden ulkomaalaistaustaisten eli maahanmuuttajavanhempien lasten politiikkaan kiinnittymistä, mikä kuitenkin nousee tulevaisuuden Suomessa yhä ajankohtaisemmaksi kysymykseksi. Vain turvaamalla eri väestöryhmien yhtäläiset osallistumismahdollisuudet voidaan ehkäistä syrjäytymistä ja kasvattaa luottamusta siihen, että poliittinen järjestelmä on oikeudenmukainen ja vastaanottavainen kaikille ihonväristä ja syntyperästä riippumatta. 


\section{TUTKIMUKSEN RAHOITUS}

Tutkimuksen aineisto on hankittu oikeusministeriön rahoituksella. Kiitän paitsi ministeriötä myös yleisen valtio-opin dosentti Hanna Wassia mahdollisuudesta käyttää aineistoa tässä väitöskirjatutkimukseeni pohjautuvassa artikkelissa. Väitöskirjatutkimustani ovat rahoittaneet Suomen Akatemia ja Kunnallisalan kehittämissäätiö.

\section{VIITTEET}

1. Ks. lisää kohdasta "Tutkimuksen rahoitus".

2. Jatkotutkimuksissa on tärkeää selvittää tarkemmin taustamaan vaikutusta Suomeen muuttaneiden poliittisiin arvoihin ja asenteisiin ja niiden muuttumiseen. Toistaiseksi tällaista selvitystä ovat Suomessa tehneet ainoastaan Pitkänen ym. (2019a; 2019b). Ruotsissa vastaavaa tutkimusta on tehnyt esim. Puranen (2019).

\section{LÄHTEET}

Al-Sharmani, Mulki ja Ismail, Abdirashid A. 2017. Marriage and Transnational Family Life among Somali Migrants in Finland. Migration Letters 14:1, 38-49.

Anniste, Kristi ja Tammaru, Tiit. 2014. Ethnic Differences in Integration Levels and Return Migration Intentions: A Study of Estonian Migrants in Finland. Demographic Research 30: 377-412. https://dx.doi.org/10.4054/DemRes.2014.30.13

Barreto, Matt A. 2010. Ethnic Cues: The Role of Shared Ethnicity in Latino Political Participation. Ann Arbor: University of Michigan. https://doi.org/10.3998/mpub.352787

Bergh, Johannes ja Bjørklund, Tor. 2011. The Revival of Group Voting: Explaining the Voting Preferences of Immigrants in Norway. Political Studies 59:2, 308-327. https://doi.org/10.1111\%2Fj.1467-9248.2010.00863.x

Bird, Karen, Saalfeld, Thomas ja Wüst, Andreas M. 2011. Ethnic Diversity, Political Participation and Representation: A Theoretical Framework. Teoksessa Karen Bird, Thomas Saalfeld ja Andreas M. Wüst (toim.), The Political Representation of Immigrants and Minorities: Voters, Parties and Parliaments in Liberal Democracies. Lontoo: Routledge, 1-21.

Black, Jerome H., Niemi, Richard G. ja Powell, G. Bingham Jr. 1987. Age, Resistance, and Political Learning in a New Environment: The Case of Canadian Immigrants. Comparative Politics 20:1, 73-84. https://doi.org/10.2307/421921

Borg, Sami. 2018. Kuntavaalitutkimus 2017. Helsinki: Kunnallisalan kehittämissäätiö.

Brady, Henry E., Verba, Sidney ja Schlozman, Kay Lehman. 1995. Beyond SES: A Resource Model of Political Participation. American Political Science Review 89:2, 271-294. https://doi.org/10.2307/2082425

Bueker, Catherine Simpson. 2005. Political Incorporation among Immigrants from Ten Areas of Origin: 
The Persistence of Source Country Effects. International Migration Review 39:1, 103-140.

Campbell, Angus, Converse, Philip E., Miller, Warren E. ja Stokes, Donald E. 1960. The American Voter. Chicago: University of Chicago Press.

Cho, Wendy. K. Tam, Gimpel, James G. ja Dyck, Joshua J. 2006. Residential Concentration, Socialization, and Voter Turnout. Journal of Politics 68:1, 156-67. https://doi.org/10.1111/j.1468-2508.2006.00377.x

Dancygier, Rafaela. 2010. Immigration and Conflict in Europe. Cambridge: Cambridge University Press.

Denver David. 2008. Another Reason to Support Marriage? Turnout and the Decline of Marriage in Britain. The British Journal of Politics and International Relations 10:4, 666-680. https://doi.org/10.1111\%2Fj.1467-856x.2008.00329.x

Deutsche Welle (2016). More women voters in Somaliland. https://www.dw.com/en/more-womenvoters-in-somaliland/a-19304266. Viitattu 23.10.2020.

Dhalmann, Hanna. 2011. Yhden uhka, toisen toive? Somalien ja venäläisten asumistoiveet etnisen segregaatiokehityksen valossa. Helsinki: Helsingin yliopisto.

European Social Survey Round 8 Data. 2016. Data file edition 2.1. NSD - Norwegian Centre for Research Data, Norway - Data Archive and distributor of ESS data for ESS ERIC. https://doi.org/10.21338/NSD-ESS8-2016

Forsander, Annika 2007. Kotoutuminen sukupuolittuneille työmarkkinoille? Maahanmuuttajien työmarkkina-asema yli vuosikymmen Suomeen muuton jälkeen. Teoksessa Tuomas Martikainen ja Marja Tiilikainen (toim.), Maahanmuuttajanaiset: Kotoutuminen, perhe ja työ. Helsinki: Väestöliitto, 312-334.

Hainmueller, Jens, Hangartner, Dominik ja Pietrantuono, Giuseppe. 2015. Naturalization fosters the long-term political integration of immigrants. Proceedings of the National Academy of Sciences 112:41, 12651-12656. https://doi.org/10.1073/pnas.1418794112

Hirvonen, Jukka. 2019. Asumisen etninen eriytyminen Helsingissä ja muualla. Kvartti 4/2019.

Huotarinen, Heini, Nurminen, Laura, Tjurin, Anniina, Vornanen, Anni, Koskinen, Atte, Kujanen, Maarika, Mäkelä, Mika, Kolehmainen, Marita, Mäenalusta, Juha ja Kariniemi, Unto. 2020. Vaalitietojärjestelmän elinkaariselvitys. Helsinki: Oikeusministeriö.

Iverson Torben ja Rosenbluth Frances. 2006. The Political Economy of Gender: Explaining CrossNational Variation in the Gender Division of Labor and the Gender Voting Gap. American Journal of Political Science 50:1, 1-19. https://doi.org/10.1111/j.1540-5907.2006.00166.x

Joronen, Tuula (2007). Työmarkkinoiden monenlaiset maahanmuuttajanaiset: Haaste suomalaiselle sukupuolijärjestelmälle. Teoksessa Tuomas Martikainen ja Marja Tiilikainen (toim.), Maahanmuuttajanaiset: Kotoutuminen, perhe ja työ. Helsinki: Väestöliitto, 285-311.

Kaihovaara, Antti, Alitolppa-Niitamo, Anne ja Kazi, Villiina. 2020. Onko maahanmuuttajien kotoutuminen epäonnistunut Suomessa? Talous \& Yhteiskunta 2/2020. https://abour.fi/t\&y/onko-maahanmuuttajien-kotoutuminen-epaonnistunut-suomessa/. Viitattu 28.10.2020.

Kananen, Marko ja Ronkainen, Jussi. 2020. Finnish-Russian Dual Citizens and the Changing Political Climate of Supranational Citizenship. Teoksessa Mabel Ann Brown (toim.), International Perspectives on Inclusion within Society and Education. Lontoo: Routledge, 57-69.

Karp, Jeffrey A. ja Brockington, David. 2005. Social Desirability and Response Validity: A Comparative Analysis of Overreporting Voter Turnout in Five Countries. Journal of Politics 67:3, 825-840. https://doi.org/10.1111/j.1468-2508.2005.00341.x 
Keating, Michael ja Waldman, Matt. (toim.) 2018. War and Peace in Somalia: National Grievances, Local Conflict and Al-Shabaab. New York: Oxford University Press.

Kuusio, Hannamaria, Lämsä, Riikka, Kazi, Villiina ja Leemann, Lars. 2020. Sosiaalinen ja poliittinen osallistuminen. Teoksessa Hannamaria Kuusio, Anna Seppänen, Satu Jokela, Laura Somersalo ja Eero Lilja (toim.), Ulkomaalaistaustaisten terveys ja hyvinvointi Suomessa. FinMonik-tutkimus 2018-2019. Helsinki: Terveyden ja hyvinvoinnin laitos, 69-74.

Kährik, Anneli ja Tammaru, Tiit. 2019. Virolaiset Suomessa. https://www.tuglas.fi/virolaiset-suomessa. Viitattu 28.10.2020.

Lagerspetz, Mikko. 2020. Suomen virolaiset - vähemmistö, väestöryhmä, vai jotakin muuta? Teoksessa Rolle Alho ja Kaja Kumer-Haukanõmm (toim.), Liikkuvuus, muuttoliike ja ylirajaiset suhteet Suomen ja Viron välillä. Turku: Siirtolaisuusinstituutti, 123-140.

Larja, Liisa. 2019. Maahanmuuttajanaiset työmarkkinoilla ja työmarkkinoiden ulkopuolella. Teoksessa Villiina Kazi, Anne Alitolppa-Niitamo ja Antti Kaihovaara (toim.), Kotoutumisen kokonaiskatsaus 2019. Tutkimusartikkeleita kotoutumisesta. Helsinki: Työ- ja elinkeinoministeriö, 28-42.

Maahanmuuttovirasto. 2020. Kansalaisuushakemus: Kielitaito. https://migri.fi/kielitaito. Viitattu 20.10.2020.

Morales, Laura ja Giuni, Marco. 2011. Political Opportunities, Social Capital and the Political Inclusion of Immigrants in European Cities. Teoksessa Laura Morales ja Marco Giugni (toim.), Social Capital, Political Participation and Migration in Europe: Making Multicultural Democracy Work? Basingstoke: Palgrave Macmillan, 1-18.

Morales, Laura ja Pilati, Katia. 2011. The Role of Social Capital in Migrants' Engagement in Local Politics in European Cities. Teoksessa Laura Morales ja Marco Giugni (toim.), Social Capital, Political Participation and Migration in Europe: Making Multicultural Democracy Work? Basingstoke: Palgrave Macmillan, 87-114.

Mubarak, Yusuf M., Nilsson, Eva ja Saxén, Niklas. 2015. Suomen Somalit. Helsinki: Into.

Myllyniemi, Sami. 2014. Tilasto-osio: Oma vaikuttamistoiminta. Teoksessa Sami Myllyniemi (toim.), Vaikuttava osa. Nuorisobarometri 2013. Helsinki: Nuorisoasiain neuvottelukunta, Nuorisotutkimusverkosto, 25-36.

Paxton, Pamela, Kunovich, Sheri ja Hughes, Melanie M. 2007. Gender in Politics. Annual Review of Sociology 33:1, 263-284. https://doi.org/10.1146/annurev.soc.33.040406.131651

Persson, Mikael, Solevid, Maria ja Öhrvall, Richard. 2013. Voter Turnout and Political Equality: Testing the 'Law of Dispersion' in a Swedish Natural Experiment. Politics 33:3, 172-184. https://doi.org/10.1111/1467-9256.12012

Persson, Mikael. 2015. Education and Political Participation. British Journal of Political Science 45:3, 689-703. https://doi.org/10.1017/S0007123413000409

Pirkkalainen, Päivi, Wass, Hanna ja Weide, Marjukka. 2016. Suomen somalit osallistuvina kansalaisina. Yhteiskuntapolitiikka 81:1, 69-77.

Pikkala Sari, Pekola-Sjöblom, Marianne ja Piipponen, Sirkka-Liisa. 2013. Kuntademokratian tila ja trendit. Teoksessa Sami Borg (toim.), Demokratiaindikaattorit 2013. Helsinki: Oikeusministeriö, 123-156.

Pirkkalainen, Päivi. 2013. Transnational responsibilities and multi-sited strategies: Voluntary associations of Somali diaspora in Finland. Jyväskylä: Jyväskylän yliopisto.

Pitkänen, Ville, Saukkonen, Pasi ja Westinen, Jussi. 2019a. Ollako vai eikö olla? Tutkimus viiden kieliryhmän kiinnittymisestä Suomeen. Helsinki: e2 Tutkimus. 
Pitkänen, Ville, Saukkonen, Pasi ja Westinen, Jussi. 2019b. Samaa vai eri maata? Tutkimus viiden kieliryhmän arvoista ja asenteista Suomessa. Helsinki: e2 Tutkimus.

Pop-Eleches, Grigore ja Tucker, Joshua A. 2011. Communism's Shadow: Postcommunist Legacies, Values, and Behavior. Comparative Politics 43:4, 379-399. https://www.jstor.org/stable/23040635

Puranen, Bi. 2019. Med migranternas röst. Den subjektiva integrationen. Tukholma: Institutet för Framtidsstudier.

Puuronen, Vesa. 2011. Rasistinen Suomi. Helsinki: Gaudeamus.

Pyykkönen, Miikka. 2007. Järjestäytyvät diasporat. Etnisyys, kansalaisuus, integraatio ja hallinta maahanmuuttajien yhdistystoiminnassa. Jyväskylä: Jyväskylän yliopisto.

Rask, Shadia, Castaneda, Anu ja Seppänen, Anna. 2020. Syrjintä- ja väkivaltakokemukset. Teoksessa Hannamaria Kuusio, Anna Seppänen, Satu Jokela, Laura Somersalo ja Eero Lilja (toim.), Ulkomaalaistaustaisten terveys ja hyvinvointi Suomessa. FinMonik-tutkimus 2018-2019. Helsinki: Terveyden ja hyvinvoinnin laitos, 91-96.

Robinson, Neil. 2018. Contemporary Russian Politics: An Introduction. Cambridge: Polity Press.

Ronkainen, Jussi. 2009. Väliviivakansalaiset. Monikansalaisuus asemana ja käytäntönä. Joensuu: Joensuun yliopisto.

Saarts, Tõnis ja Jakobson, Mari-Liis. 2019. Civic Engagement in Policy Making Processes in Estonia: A Controversial Success Story. Der Donauraum 56:1-2, 25-38.

https://doi.org/10.7767/dedo.2016.56.1-2.25

Saukkonen, Pasi. 2020. Suomi omaksi kodiksi. Kotouttamispolitiikka ja sen kehittämismahdollisuudet. Helsinki: Gaudeamus.

von Schoultz, Åsa. 2018. Electoral Systems in Context: Finland. Teoksessa Erik S. Herron, Robert J. Pekkanen ja Matthew S. Shugart (toim.), The Oxford Handbook of Electoral Systems. New York: Oxford University Press, 601-626. https://doi.org/10.1093/oxfordhb/9780190258658.013.4

Sipinen, Josefina ja Koskimaa, Vesa. 2020. Ehdokkaiden taustaominaisuuksien merkitys ehdokasasettelussa. Teoksessa: Elina Kestilä-Kekkonen ja Åsa von Schoultz (toim.), Ehdokkaat vaalikentillä. Eduskuntavaalit 2019. Helsinki: Oikeusministeriö, 24-56.

Sipinen, Josefina. 2021. Recruitment of Immigrant-origin Candidates in Finnish Municipal Elections. Tampere: Tampereen yliopisto.

Sutela, Hanna ja Larja, Liisa. 2015. Maahanmuuton syyt: Yli puolet Suomen ulkomaalaistaustaisista muuttanut maahan perhesyistä. Teoksessa Tarja Nieminen, Hanna Sutela ja Ulla Hannula (toim.), Ulkomaista syntyperää olevien työ ja hyvinvointi Suomessa 2014. Helsinki: Tilastokeskus, 15-25.

Sveriges Riksdag. 2019. The history of the Riksdag. https://www.riksdagen.se/en/how-the-riksdagworks/democracy/the-history-of-the-riksdag/. Viitattu 14.9.2020.

Tanner, Arno ja Söderling, Ismo (toim.). 2016. Venäjänkieliset Suomessa. Huomisen suomalaiset. Turku: Siirtolaisuusinstituutti.

Tiilikainen, Marja (toim.). 2014. Somalit Helsingissä. New York: Open Society Foundations.

Tiilikainen, Marja ja Hassan Mohamed, Abdirizak. 2013. Civil Society in Making: Challenges of the Somali Diaspora Organizations. Nordic Journal of Migration Research 3:1, 40-48. https://doi.org/10.2478/v10202-012-0013-9

Tilastokeskus. 2018. Väestöryhmien tulot ja tuloerot http://www.stat.fi/til/tjt/2018/06/ tjt_2018_06_2020-03-12_kat_002_fi.html. Viitattu 23.10.2020.

Tilastokeskus. 2020a. Väestö syntyperän ja taustamaan, iän ja sukupuolen mukaan, 1990-2019. 
http://pxnet2.stat.fi/PXWeb/pxweb/fi/Maahanmuuttajat_ja_kotoutuminen/Maahanmuuttajat_ja_ kotoutuminen_Maahanmuuttajat_ja_kotoutuminen/maakoto_pxt_11vy.px/. Viitattu 31.12.2020.

Tilastokeskus. 2020b. Syntyperä ja taustamaa sukupuolen mukaan kunnittain, 1990-2019. http:// pxnet2.stat.fi/PXWeb/pxweb/fi/StatFin/StatFin__vrm_vaerak/statfin_vaerak_pxt_11rv.px/.Viitattu 31.12.2020.

Tilastokeskus. 2020c. Maahan- ja maastamuutto muuttomaan, sukupuolen ja kielen mukaan, 19902019. http://pxnet2.stat.fi/PXWeb/pxweb/fi/Maahanmuuttajat_ja_kotoutuminen/Maahanmuuttajat_ja_kotoutuminen_Maahanmuuttajat_ja_kotoutuminen/maakoto_pxt_11w1.px/.Viitattu 31.12.2020.

Työ- ja elinkeinoministeriö (2020). Kotoutumisen indikaattorit. Kototietokanta. http://kototietokanta. stat.fi/PXWeb/pxweb/fi/Kotoutumisenindikaattorit. Viitattu 20.10.2020.

Wahlbeck, Östen. 2015. Inflyttad från Sverige: en studie av rikssvenska erfarenheter i Helsingfors. Möklinta: Gidlunds förlag.

Varjonen, Sirkku, Zamiatin, Aleksandr ja Rinas, Marina. 2017. Suomen venäjänkieliset. Tässä ja nyt. Tilastot, tutkimukset, järjestökentän kartoitus. Helsinki: Cultura-säätiö.

Valaste, Maria ja Wass, Hanna. 2019. Poliittinen osallistuminen osana kokonaisvaltaista kotoutumista. Teoksessa Villiina Kazi, Anne Alitolppa-Niitamo ja Antti Kaihovaara (toim.), Kotoutumisen kokonaiskatsaus 2019. Tutkimusartikkeleita kotoutumisesta. Helsinki: Työ- ja elinkeinoministeriö.

Wass, Hanna ja Borg, Sami. 2016. Yhdenvertaisuus äänestyskopissa. Äänestysaktiivisuus vuoden 2015 eduskuntavaaleissa. Teoksessa Kimmo Grönlund ja Hanna Wass (toim.), Poliittisen osallistumisen eriytyminen. Eduskuntavaalitutkimus 2015. Helsinki: Oikeusministeriö, 177-199.

Wass, Hanna ja Weide, Marjukka. 2015. Ä̈̈nestäminen osana poliittista kansalaisuutta. Maahanmuuttotaustaisten äänioikeutettujen osallistuminen vuoden 2012 kunnallisvaaleissa. Helsinki: Oikeusministeriö.

Wass, Hanna, Blais, André, Morin-Chassé, Alexandre ja Weide, Marjukka. 2015. Engaging Immigrants? Examining the Correlates of Electoral Participation among Voters with Migration Backgrounds. Journal of Elections, Public Opinion and Parties 25:4, 407-424. https://doi.org/10.1080/17457289.2015.1023203

Weide, Marjukka ja Saukkonen, Pasi. 2013. Maahanmuuttajien poliittinen osallistuminen. Teoksessa Tuomas Martikainen, Pasi Saukkonen ja Minna Säävälä (toim.), Muuttajat: kansainvälinen muuttoliike ja suomalainen yhteiskunta. Helsinki: Gaudeamus, 262-280.

Verba, Sidney ja Nie, Norman H. 1972. Participation in America: Political Democracy and Social Equality. New York: Harper.

Verba, Sidney, Lehman Schlozman, Kay ja Burns, Nancy. 2005. Family Ties: Understanding the Intergenerational Transmission of Political Participation. Teoksessa Alan S. Zuckerman (toim.), The Social Logic of Politics: Personal Networks as Contexts for Political Behavior. Philadelphia: Temple Universtiy Press, 95-114.

Vermeulen, Floris, Kranendonk Maria ja Michon Laure. 2020. Immigrant Concentration at the Neighbourhood Level and Bloc Voting: The Case of Amsterdam. Urban Studies 57:4, 766-788. https://doi.org/10.1177\%2F0042098019859490

Winkler, Adam. 1993. Expressive voting. New York University Law Review 68:2, 330-388.

Witting, Mika. 2019. Korkeasti koulutettuja ja vähän koulutettuja. Ulkomaalaistaustaisten koulutuksesta tulossa tarkempaa tietoa. http://www.tilastokeskus.fi/tietotrendit/blogit/2019/korkeasti-koulutettuja- 
ja-vahan-koulutettuja-ulkomaalaistaustaisten-koulutuksesta-tulossa-tarkempaa-tietoa/. Viitattu 28.9.2020.

Wolfinger, Nicholas. H. ja Wolfinger, Raymond, E. 2008. Family Structure and Voter Turnout. Social Forces 86:4, 1513-1528. https://www.jstor.org/stable/20430819

\section{KIRJOITTAJATIEDOT}

JOSEFINA SIPINEN

YTT, FM, postdoc-tutkija

Politiikan tutkimus

Johtamisen ja talouden tiedekunta

Tampereen yliopisto

josefina.sipinen@tuni.fi 
Liitetaulukko 1. Äänestystodennäköisyyteen vaikuttavat sosiodemografiset ja -ekonomiset taustatekijät. Logistinen regressioanalyysi. Vetosuhde (odds ratio) ja sulkeissa keskivirhe

\begin{tabular}{|c|c|c|c|c|c|}
\hline & Suomalaistaustaiset & Venäläistaustaiset & Virolaistaustaiset & Somalialaistaustaiset & Ruotsalaistaustaiset \\
\hline Nainen (ref. mies) & $1,173(, 005)^{* * *}$ & $1,318(, 066)^{* * *}$ & $1,537(, 102)^{* * *}$ & $967(, 103)$ & $1,330(, 248)$ \\
\hline \multicolumn{6}{|l|}{ Ikäryhmä (ref. 18-29) } \\
\hline $30-39$ & $1,105(, 008)^{* * *}$ & $1,300(, 114)^{* *}$ & $1,613(, 190)^{* * *}$ & $1,533(, 204)^{* *}$ & $2,507(1,001)^{*}$ \\
\hline $40-49$ & $1,315(, 010)^{* * *}$ & $1,508(, 134)^{* * *}$ & $2,271(, 270)^{* * *}$ & $1,846(, 296)^{* * *}$ & $3,574(1,432)^{* *}$ \\
\hline $50-59$ & $1,652(, 013)^{* * *}$ & $1,966(, 174)^{* * *}$ & $3,017(, 365)^{* * *}$ & $1,333(, 242)$ & $3,218(1,316)^{* *}$ \\
\hline $60-69$ & $2,653(, 023)^{* * *}$ & $2,412(, 238)^{* * *}$ & $3,783(, 536)^{* * *}$ & $2,334(, 738)^{*}$ & $5,377(2,509)^{* * *}$ \\
\hline $70-$ & $2,478(, 026)^{* * *}$ & $2,505(, 377)^{* * *}$ & $4,073(1,021)^{* * *}$ &, $562(, 269)$ & $3,825(1,997)^{*}$ \\
\hline \multicolumn{6}{|l|}{ Ammattiasema (ref. työntekijät) } \\
\hline $\begin{array}{l}\text { Yrittäjät (ml. maa- ja } \\
\text { metsätalousyrittäjät) }\end{array}$ & $1,705(, 017)^{* * *}$ & $1,345(, 154)^{*}$ & $1,194(, 156)$ & $1,170(1,038)$ & $4,288(2,044)^{* *}$ \\
\hline Ylemmät toimihenkilöt & $2,782(, 024)^{* * *}$ & $2,291(, 204)^{* * *}$ & $3,989(, 469)^{* * *}$ & $965(, 329)$ & $5,707(2,192)^{* * *}$ \\
\hline Alemmat toimihenkilöt & $1,510(, 010)^{* * *}$ & $1,497(, 113)^{* * *}$ & $1,697(, 154)^{* * *}$ & $1,050(, 267)$ & $2,786(, 976)^{* *}$ \\
\hline Opiskelijat & $2,169(, 021)^{* * *}$ & $1,678(, 168)^{* * *}$ & $1,785(, 260)^{* * *}$ & $1,457(, 309)$ & $7,398(4,068)^{* * *}$ \\
\hline Eläkeläiset & $1,351(, 012)^{* * *}$ & $1,818(, 217)^{* * * *}$ & $1,660(, 279)^{* *}$ & $1,458(, 521)$ & $2,810(1,311)^{*}$ \\
\hline Muut / tuntematon & $1,233(, 010)^{* * *}$ & $1,352(, 100)^{* * *}$ & $1,294(, 115)^{* *}$ & $1,360(, 264)$ & $2,011(, 696)^{*}$ \\
\hline \multicolumn{6}{|l|}{$\begin{array}{l}\text { Henkilökohtaiset tulot e/v } \\
\text { (ref. 0-14000) }\end{array}$} \\
\hline $15000-25000$ & $1,410(, 008)^{* * *}$ & $1,130(, 074)$ & $1,022(, 090)$ & ,951 (,189) & $2,032(, 495)^{* *}$ \\
\hline $26000-37000$ & $1,804(, 011)^{* * *}$ & $1,059(, 079)$ & $1,111(, 105)$ & $1,125(, 292)$ & $2,628(, 722)^{* * *}$ \\
\hline $38000-$ & $2,211(, 015)^{* * *}$ & $1,133(, 097)$ & $1,153(, 121)$ & $1,390(, 451)$ & $1,914(, 545)^{*}$ \\
\hline \multicolumn{6}{|l|}{$\begin{array}{l}\text { Puolison kansalaisuus } \\
\text { (ref. puoliso Suomen kansalainen) }\end{array}$} \\
\hline Puoliso ulkomaan kansalainen &, $578(, 014)^{* * *}$ &, $581(, 037)^{* * *}$ &, $331(, 033)^{* * *}$ & $1,070(, 208)$ &, $117(, 094)^{* *}$ \\
\hline Ei puolisoa &, $502(, 002)^{* * *}$ &, $576(, 029)^{* * *}$ &, $312(, 025)^{* * *}$ & ,727 $(, 108)^{*}$ &, $547(, 099)^{* *}$ \\
\hline $\begin{array}{l}\text { Suomen kansalainen } \\
\text { (ref. muu kansalaisuus) }\end{array}$ & $2,61(, 167)^{* * *}$ & $1,911(, 094)^{* * *}$ & $2,498(, 186)^{* * *}$ &, $956(, 104)$ & $1,594(, 323)^{*}$ \\
\hline Vakio &, $221(, 014)^{* * *}$ &, $091(, 010)^{* * *}$ &, $079(, 012)^{* * *}$ & $1,007(, 246)$ &, $082(, 040)^{* * *}$ \\
\hline N & 1275669 & 13500 & 12932 & 1622 & 663 \\
\hline Nagelkerke $\mathrm{R}^{2}$ & ,152 & ,102 & , 185 &, 042 & ,224 \\
\hline
\end{tabular}

${ }^{*} \mathrm{p}<, 05 ;{ }^{* *} \mathrm{p}<, 01 ;{ }^{* *} \mathrm{p}<, 001$ 